\title{
Three-Dimensional Surface Deformation Characteristics Based on Time Series InSAR and GPS Technologies in Beijing, China
}

\author{
Kunchao Lei ${ }^{1,2}{ }^{\oplus}$, Fengshan Ma ${ }^{1, *}$, Beibei Chen ${ }^{3,4}$, Yong Luo ${ }^{2}$, Wenjun Cui ${ }^{2}$, Yi Zhou ${ }^{5}$, He Liu ${ }^{2}$ and Te Sha ${ }^{2}$ \\ 1 Key Laboratory of Shale Gas and Geoengineering, Institute of Geology and Geophysics, Chinese Academy of \\ Sciences, Beijing 100029, China; leikunchao@mail.iggcas.ac.cn \\ 2 Beijing Institute of Hydrogeology and Engineering Geology, Beijing 100195, China; \\ luoyong@bjswd.com (Y.L.); cwj@bjswd.com (W.C.); liuhe@bjswd.com (H.L.); st@bjswd.com (T.S.) \\ 3 College of Resource Environment and Tourism, Capital Normal University, Beijing 100048, China; \\ 6183@cnu.edu.cn \\ 4 Key Laboratory of Mechanism, Prevention and Mitigation of Land Subsidence, MOE, Beijing 100048, China \\ 5 Beijing Institute of Geology and Mineral Exploration, Beijing 100195, China; zhouyi@bjswd.com \\ * Correspondence: fsma@mail.iggcas.ac.cn
}

check for

updates

Citation: Lei, K.; Ma, F.; Chen, B.; Luo, Y.; Cui, W.; Zhou, Y.; Liu, H.; Sha,

T. Three-Dimensional Surface

Deformation Characteristics Based on

Time Series InSAR and GPS

Technologies in Beijing, China.

Remote Sens. 2021, 13, 3964. https://

doi.org/10.3390/rs13193964

Academic Editor:

Alessandro Bonforte

Received: 7 September 2021

Accepted: 29 September 2021

Published: 3 October 2021

Publisher's Note: MDPI stays neutral with regard to jurisdictional claims in published maps and institutional affiliations.

Copyright: (c) 2021 by the authors. Licensee MDPI, Basel, Switzerland. This article is an open access article distributed under the terms and conditions of the Creative Commons Attribution (CC BY) license (https:/ / creativecommons.org/licenses/by/ $4.0 /$ )

\begin{abstract}
Excessive exploitation of the groundwater has resulted in obvious three-dimensional (3D) deformation features on the surface of the Beijing Plain. This paper, by combining Interferometric Synthetic Aperture Radar (InSAR) and Global Positioning System (GPS) technologies, has obtained time-series information of the 3D surface deformation in the Beijing Plain, analyzing its spatial distribution characteristics. On this basis, the relationship between different controlling factors with the 3D deformation of the surface has been analyzed as well. The following results are obtained: (1) From 2013 to 2018, the land subsidence, which generally showed the trend of slowing down, was mainly concentrated in the eastern, northern, and southern regions of Beijing Plain, with multiple subsidence centers. (2) Under the International Terrestrial Reference Frame 2005 (ITRF2005), the horizontal direction of all GPS points in the plain is basically the same, with the dominant movement direction being NE112.5 $\sim \mathrm{NE} 113.8^{\circ}$. Under the Eurasian reference frame, the horizontal movement rate of GPS points significantly decreases. The movement rate and direction of each point are not characteristic of overall trend activity. (3) The distribution and extent of the 3D surface deformation in the Beijing Plain are controlled by the basement structure. Part of the subsided area corresponds to a Quaternary depression formed at the junction of active faults disrupting the area. Similarly, the distribution of horizontal deformation in the E-W and N-S directions of the plain is controlled by the regional basement structure comprising major faults bounding horizontal deformation. (4) Groundwater exploitation is the main cause of the 3D surface deformation in the Beijing Plain. The groundwater funnels of the second and third confined aquifer are in suitable agreement with the land subsidence. The horizontal movement in the Beijing Plain is either directed toward the center of the groundwater or the land subsidence funnel, and the deformation is directed from areas with higher to areas with lower groundwater levels.
\end{abstract}

Keywords: InSAR; GPS; 3D deformation; basement structure; groundwater extraction

\section{Introduction}

The surface deformation caused by many geophysical phenomena, to some extent, manifests the characteristics of 3D deformation, such as tectonic movements, active faults, earthquakes, volcanic eruptions, and land subsidence [1-3]. The accurate acquisition of the 3D deformation field information of these geophysical phenomena reveals the important role of geological data in the identification of their internal mechanism, movement process, and development trend [4-6]. Beijing is one of the few super-large cities in the world that use groundwater as the main source of water supply. The amount of groundwater extraction accounts for $50 \sim 70 \%$ of the total water supply of the city [7]. 
As a result, the groundwater resources have been over-exploited for a long time. From 1961 to 2018, the cumulative loss of groundwater resources was 9.6 billion cubic meters, which gave rise to serious surface deformation problems in the Quaternary strata of the plain $[8,9]$. In previous studies, most scholars concentrated on the vertical consolidation and compaction deformation of porous media caused by excessive groundwater extraction, which is land subsidence. By means of a large amount of observation data, they studied the acquisition of land subsidence monitoring information [10-15], the evolution law of land subsidence [16-21], as well as the causal mechanism of land subsidence [22-29], and up to now, they have obtained fruitful research results. However, there are few studies on the horizontal movement or deformation characteristics of the porous medium solid skeleton caused by the extraction of groundwater. The main reason is that the horizontal movement of porous media is not as intuitive and easy to monitor as the vertical consolidation and the compaction deformation [30,31]. A large amount of evidence shows that the horizontal movement and the deformation of the aquifer caused by pumping do exist, however [32-35].

Currently, Global Positioning System (GPS) and Interferometric Synthetic Aperture Radar (InSAR) methods are often used to monitor surface deformation in a large-scale area. The advantage of GPS technology lies in the high measurement accuracy and sensitivity of the ground displacement in the horizontal direction (E, $\mathrm{N}$ direction). With a longer observation period, the millimeter-level horizontal displacement on the ground can be detected by means of GPS technology [4]. However, the monitoring accuracy in the vertical direction is 2-3 times lower than that in the horizontal direction [6]. The advantage of InSAR technology lies in its large-scale measurement based on the image surface, which is characteristic of high spatial resolution, wide coverage, and spatial non-contact remote sensing, and that can effectively obtain the continuous surface deformation information, especially for large-scale surface deformation [36-43]. Time series InSAR analysis techniques, such as Permanent Scatters (PS) and Small Baseline Subset (SBAS) developed in recent years, have widely applied to surface deformation monitoring [43]. Due to the characteristics of side-view imaging of SAR sensors, InSAR is more sensitive to the vertical deformation of the surface, but it is difficult to detect horizontal deformations in the N-S direction. Because of this, the technology is restricted in the acquisition of 3D deformation information and the interpretation of corresponding geophysical mechanisms [6]. In previous studies, most scholars monitored the vertical deformation of the ground surface by using Envisat ASAR, Radarsat-2, Alos PALSAR, TerraSAR-X, and Sentinel-1 SAR data sets, and used InSAR technology $[18,19,25,26,29]$, or monitored the crust horizontal movement characteristics by using GPS technology [44-48]. However, there are few studies on the combination of InSAR and GPS technology to obtain the 3D deformation characteristics of the surface caused by over-exploitation of groundwater. Therefore, so as to obtain complete 3D surface deformation information and further clarify the mechanism of surface deformation, it is very meaningful to combine the high-precision GPS horizontal displacement measurement with the high-density InSAR vertical deformation measurement $[5,6,46]$.

This paper has obtained the time-series information of the 3D surface deformation field in the Beijing Plain area by using InSAR and GPS technology and analyzing its spatial distribution and evolution characteristics and laws. On this basis, the observation data of regional structure, groundwater flow field, and groundwater level are couple analyzed with the monitoring results of the surface 3D deformation field, with the relationship analyzed between different controlling factors with the 3D deformation of the surface. The research contents are mainly composed of the three following aspects. Firstly, by means of the Permanent Scatterers InSAR (PS-InSAR) and GPS technology, the vertical deformation in the plain area from 2013 to 2018 is obtained, and the evolution law is analyzed. Secondly, with the GPS observation data from 2013 to 2018 processed and calculated, the 3D coordinates of GPS points are obtained under the International Terrestrial Reference Frame 2005 (ITRF2005) and the Eurasian reference frame, respectively. Then the horizontal movement characteristics of GPS points under the two reference frames 
are analyzed. Thirdly, the different controlling factors are analyzed with the monitoring results of the 3D deformation, with the response relationship identified between the 3D deformation and multiple controlling factors. The results of this paper can be used to provide an important data basis and reference for further research on the causal mechanism of the 3D deformation and the construction of the water-soil 3D model in the Beijing Plain.

\section{Description of the Study Area}

Beijing is located on the northwestern edge of the North China Plain. The terrain is generally higher in its northwest part and lower in its southeastern part. It is surrounded by the Taihang Mountains in the west, the Yanshan Mountains in the north, and the inclined plain in the southeast. The geographical coordinates of Beijing are E115. $7^{\circ} \sim 117.4^{\circ}$ and $\mathrm{N} 39.4^{\circ} \sim 41.6^{\circ}$, and its total area is $16410 \mathrm{~km}^{2}$, the plain one of which is $6400 \mathrm{~km}^{2}$ accounting for $39 \%$ of the total area [49]. The main structure of the Beijing Plain was formed during the Mesozoic Yanshan Movement and has been further transformed by the Himalayan Movement since the Cenozoic [50]. The depth of the underlying bedrock in the plain area varies greatly and is disrupted by several faults, including the NE(NNE) -SW(SSW) striking Huangzhuang-Gaoliying, Shunyi, Nanyuan-Tongxian, and Xia Dian-Mafang faults and the NW-SE direction Nankou-Sunhe fault (Figure 1). The Quaternary stratum is mainly formed by the alluvial-diluvial effect of five rivers, which are Yongding, Chaobai, Beiyun, Daqing, and Jiyun rivers [50]. On the top of the alluvial fan, the 20-40 m-thick Quaternary deposits comprise a single layer of sand or gravel or a thin layer of cohesive soil on the top of sand or gravel. In the middle and lower parts of alluvial fans and alluvial plains, the sediment thickness and the layers increase while the grain size decreases. The lithology becomes sand, gravel, and cohesive soil, alternately. Among them, the cohesive soil layer is the main stratum [24] (Figure 1).

Corresponding to the sedimentary characteristics of the Quaternary, the aquifer system in the Beijing Plain can be vertically divided into three main aquifer groups. The first aquifer system (unconfined aquifer and shallow confined aquifer) are the Holocene (Q4) and Upper Pleistocene (Q3) alluvial deposits, which reach bottom depths of about $25 \mathrm{~m}$ and $80 \sim 120 \mathrm{~m}$, respectively. The second aquifer system (medium-deep confined aquifers) is a multi-layered structure of the Middle Pleistocene (Q2) strata, the lithology of which is mainly medium-coarse sand, partly with gravel, and the bottom depth of which is about $300 \mathrm{~m}$. The third aquifer system (deep confined aquifers) is the Lower Pleistocene (Q1) stratum with a multi-layer structure, which is dominated by medium-coarse sand and gravel and is lain over the basement rocks [51] (Figure 2).

Corresponding to the division of Quaternary aquifer groups, the soil layers in the plain can be divided into three main compression layer groups. The first compression group $(\mathrm{Q} 4+\mathrm{Q} 3)$ is widely distributed in the Beijing Plain Area. Its lithology comprises Upper Pleistocene alluvial facies, alluvial silt, and cohesive soil, and its bottom depth is less than $100 \mathrm{~m}$. The second compression group (Q2) is mainly distributed in the middle and lower parts of the Beijing Plain Area. Its lithology comprises Middle Pleistocene alluvial and alluvial lacustrine facies, silt, silty clay, and clay, and its bottom depth is less than $300 \mathrm{~m}$. The third compression group (Q1) is mainly distributed in the center of several major sedimentary depressions. Its lithology comprises Lower Pleistocene alluvial and alluvial lacustrine facies, silty clay, and clay, and its roof depth is greater than $300 \mathrm{~m} \mathrm{[24,51]}$ (Figure 2). 


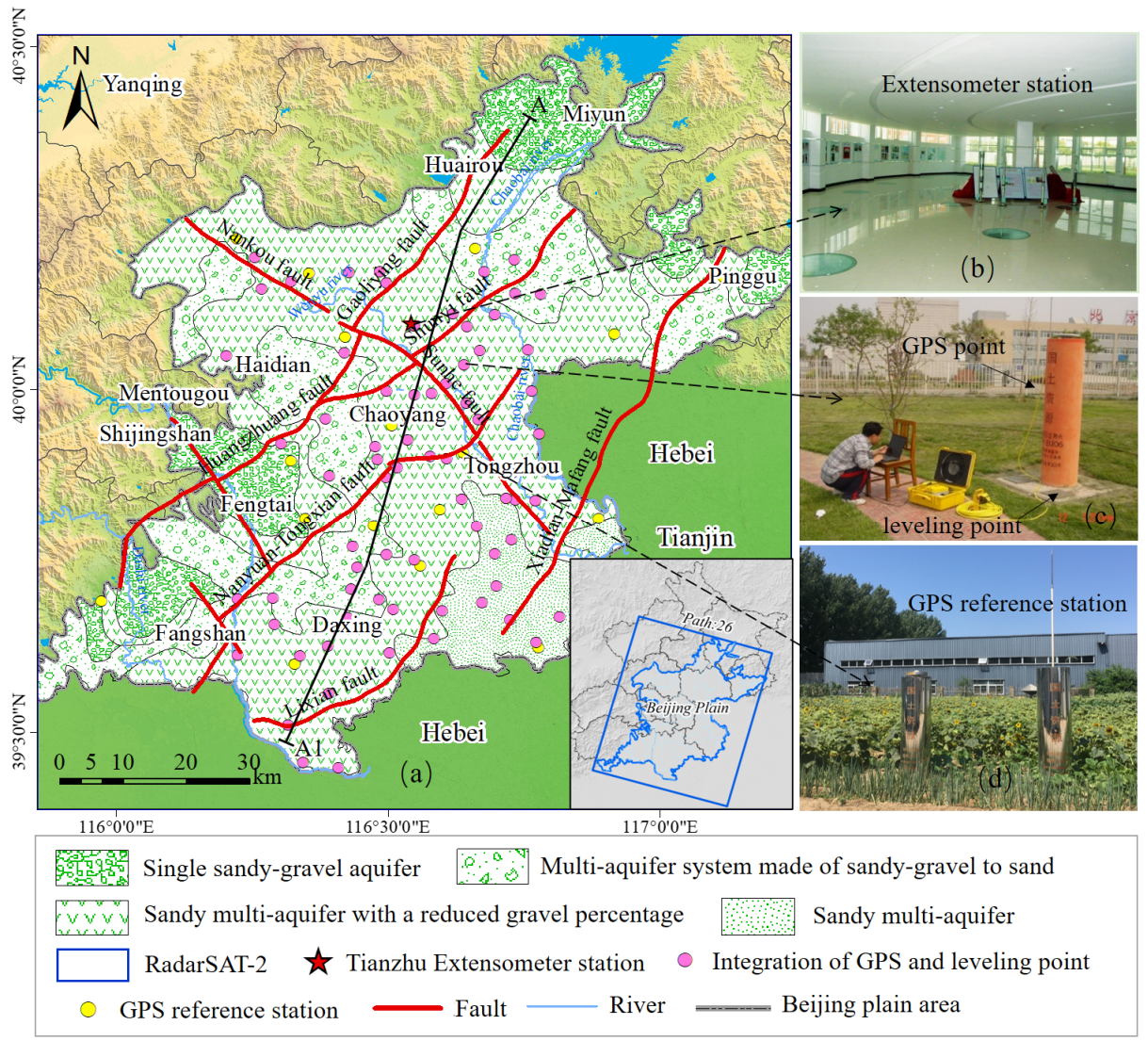

Figure 1. (a) The location and geological conditions of the Beijing Plain. The position of the Tianzhu extensometer station, InSAR coverage, GPS and leveling integrated points, and CORS stations are provided. Hydrogeologic cross-section of Beijing alluvial-proluvial fan along the north to south A-A1 traced in Figure 2. (b) Tianzhu Extensometer Station. (c) GPS and leveling integrated point and GPS measurement. (d) The continuous operation reference station of GPS(CORS).

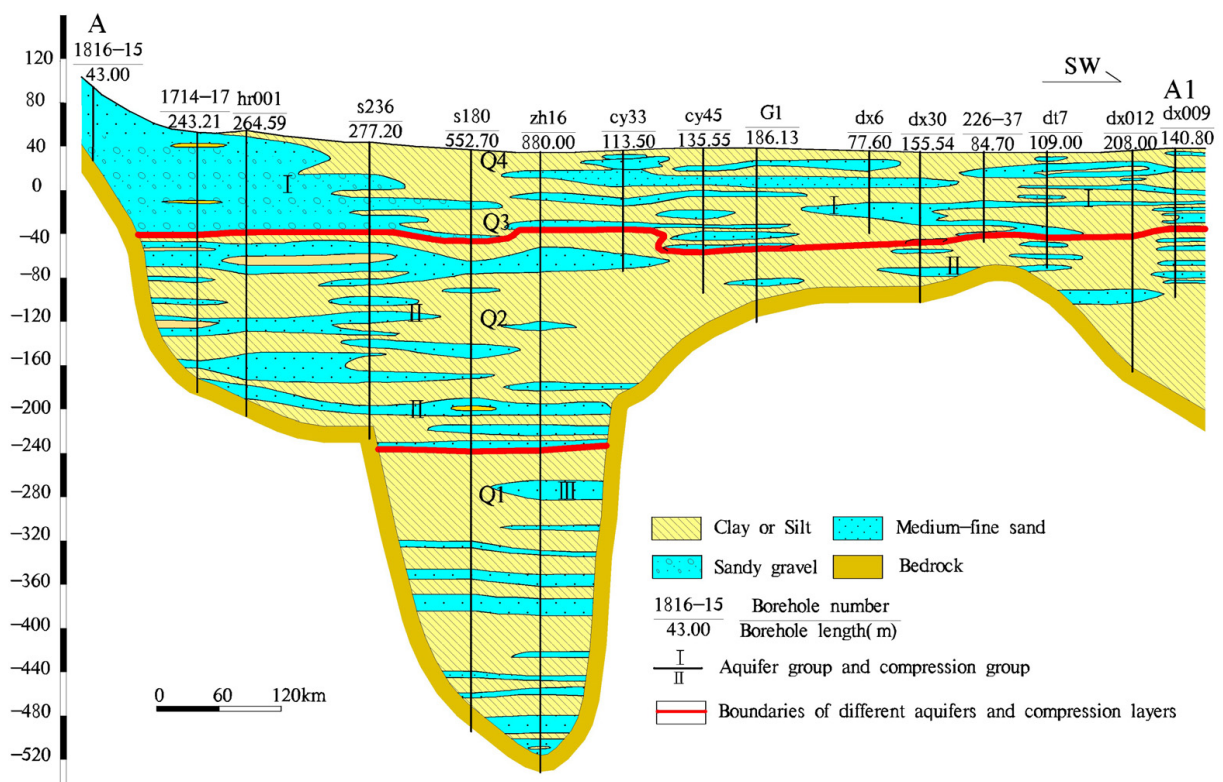

Figure 2. Hydrogeologic cross-section of Beijing alluvial-proluvial fan along the north to south A-A1 (the location is shown in Figure 1). 


\section{Data sets and Methods}

3.1. Data Sets

\subsubsection{SAR Data}

54 RadarSAT-2 images that covered the Beijing Plain are selected as the data source for interference processing (Wide strip format). The acquisition parameters of SAR images are presented in Table 1.

Table 1. Acquisition parameters of Radarsat-2 data sets.

\begin{tabular}{cc}
\hline SAR Sensor & Radarsat-2 \\
\hline Orbit direction & Descending \\
Orbit altitude & $798 \mathrm{~km}$ \\
Band (wavelength) & C-band $(5.6 \mathrm{~cm})$ \\
Revisit cycle & 24 days \\
Spatial resolution & $30 \mathrm{~m}$ \\
Incidence angle $\left(^{\circ}\right)$ & 27.8 \\
Polarization & $\mathrm{VV}$ \\
Center location & 40.20116 .40 \\
Number of images & 54 \\
Temporal coverage & $2013 / 01 / 16-2018 / 12 / 22$ \\
\hline
\end{tabular}

\subsubsection{GPS and Leveling Data}

The GPS observation data from 2013 to 2018 in the plain are selected for the network solution and the adjustment processing. The location of GPS points is shown in Figure 1. The GPS calculation each year contains 61 GPS and leveling integrated points (leveling points are constructed at the bottom of the GPS observation piers at the same time) and 14 Continuously Operating Reference Stations (CORS). Meanwhile, 40 primary leveling data during the same period are used to verify the accuracy of InSAR and GPS monitoring results. The geodetic elevation system is used for GPS survey, and the normal elevation system is used for leveling. There is an abnormal elevation between them. However, considering that the study area is small, when the vertical deformation (elevation difference) is compared, the elevation anomaly between them can be ignored. InSAR-derived result is the line of sight (LOS) deformation. Compared with the leveling results, the line of sight (LOS) deformation must be projected to the vertical direction.

\subsubsection{Groundwater and Extensometer Data}

Extensometer deformation data and corresponding groundwater-level data observed at Tianzhu subsidence monitoring station in Shunyi District were selected to analyze the relationship between layered soil deformation and groundwater level. The extensometers placed in the Tianzhu station add up to 10, which are buried in layers of different depths, respectively. The shallowest observation horizon of the extensometer is $2.4 \sim 35.5 \mathrm{~m}$, and the deepest one is $219.0 \sim 238.1 \mathrm{~m}$. The station boasts six groundwater-level monitoring wells altogether, which are arranged to monitor the water-level changes of aquifers at different depths. The shallowest observation horizon of monitoring wells is $27.5 \sim 31.0 \mathrm{~m}$, and the deepest one is $245.0 \sim 308.1 \mathrm{~m}$. At the same time, the water levels of different aquifer systems in 2017 were collected to analyze the relationship between 3D deformation.

\subsection{Methods}

The overall technical framework is shown in Figure 3. Firstly, by means of Permanent Scatterers Interferometry (PSI) technology, RadarSAT-2 images were processed to obtain vertical ground deformation information in the Beijing Plain. Meanwhile, the leveling data were used to validate the InSAR results. Secondly, with GAMIT/GLOBK software package, baseline vector calculation and network adjustment processing on GPS data were performed to obtain the horizontal deformation characteristics of GPS points under the ITRF2005 reference frame and the Eurasian reference frame, respectively. Then the 
control effect of the regional basement structure on the vertical and horizontal deformation in the plain area was studied by means of analyzing the basement structure and the 3D deformation. Finally, the impact of groundwater exploitation on the 3D surface deformation was assessed by analyzing the groundwater flow field, groundwater-level observation data, and the 3D surface deformation field.

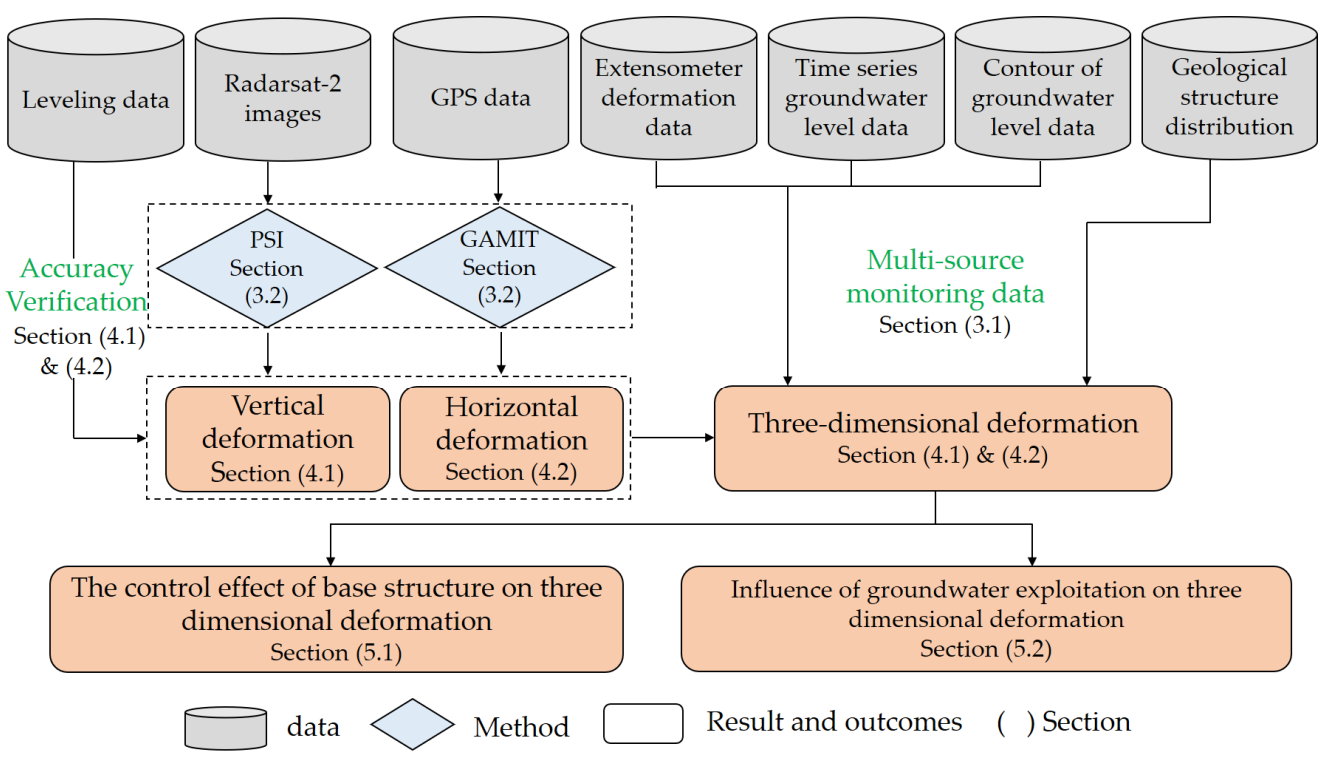

Figure 3. The flowchart of methodologies.

\subsubsection{Permanent Scatterers Interferometry (PSI) Technology}

The basic idea of PS-InSAR is to select those pixels as the research object that maintain high coherence in the long-term sequence of SAR images, and the long-term sequence stability of them enables accurate phase information to be obtained. By decomposing the phase of each coherent target point, including the elevation, the orbit, and the phase change of the atmosphere, surface deformation can be obtained. This method can effectively overcome the influence of space and time decoherence and atmospheric delay of DInSAR and improve the monitoring accuracy of surface deformation, which can reach the millimeter level. PSI technology was first developed by Ferretti [10,37], and since then, it has largely been used to measure movements of Earth's surface [52,53]. The main steps of the PSI processing chain are as follows: selection of a master image from the available series of SAR scenes, construction of a series of interferograms, selection of permanent scatterers (PS) of the radar signal according to amplitude dispersion index and coherence thresholds, and phase unwrapping. The differential interferometric phase $\Phi_{\mathrm{PS}}$ of each PS in the interferogram can be expressed as the accumulation of five components [11]:

$$
\Phi_{\mathrm{PS}}=\Phi_{\mathrm{def}}+\Phi_{\mathrm{top}}+\Phi_{\mathrm{atm}}+\Phi_{\mathrm{orb}}+\Phi_{\mathrm{n}}
$$

In the formula, $\Phi_{\text {def }}$ is the deformation phase along the line of sight (LOS), $\Phi_{\text {top }}$ the topographic phase, $\Phi_{\text {atm }}$ the phase component due to atmospheric delay, $\Phi_{\text {orb }}$ the orbital error phase, and $\Phi_{\mathrm{n}}$ the phase noise. The deformation phase $\Phi_{\text {def }}$ of PS can be separated from the other components. An external DEM with a resolution of $30 \mathrm{~m}$ is used to remove $\Phi_{\text {top }}$ from the interferometric phase. The phases due to atmosphere delay and noise are removed through filtering processes [54]. In this paper, GAMMA software is used to process 54-scene RadarSAT-2 images for time-series differential interference processing and PS point extraction. Interferometric image pairs with a baseline distance of more than $300 \mathrm{~m}$ are eliminated, and $30 \mathrm{~m}$ resolution SRTM data are used as the reference DEM. After removing the terrain phase, geocoding, and transforming the line of sight (LOS) to the vertical projection, the vertical deformation rate of the ground surface in the Beijing Plain 
area from 2013 to 2018 is obtained. The projection formula of the line of sight (LOS) to the vertical projection is as follows:

$$
\mathrm{V}=\frac{\mathrm{V}_{\mathrm{LOS}}}{\cos \varphi}
$$

where $\mathrm{V}$ and $\mathrm{V}_{\mathrm{LOS}}$ represent the displacement rate along the vertical and LOS directions, respectively; $\varphi$ is the incidence angle of the InSAR.

\subsubsection{GPS Monitoring}

The GPS network observation of deformation in Beijing has been carried out from August to October every year since 2008. The GPS observation level is class A. Each GPS point is observed continuously for 72 hours, and the CORS sampling interval is 30 seconds. Three bedrock reference points of BJFS, BJSH, and JIXN are selected as stable reference datums. The data calculation and adjustment processing are carried out from 3 bedrock reference points, 61 GPS and leveling integrated points, and 14 CORS stations by using the GAMIT/GLOBK software package. In this study, by using the GPS processing method mentioned above, the precise 3D coordinates of GPS points under the ITRF2005 framework in the plain area from 2013 to 2018 have been obtained. At the same time, the NNR-NUVEL1A model is used to subtract the Eurasian plate velocity from the horizontal velocity field under the ITRF frame in order to study the characteristics of the horizontal movement of GPS points much better. Finally, the horizontal velocity field of all GPS points in the Eurasian reference frame is obtained.

\section{Results}

\subsection{Vertical Deformation}

\subsubsection{Regional Land Subsidence Characteristics}

The time-series information of the vertical deformation of the Beijing Plain from 2013 to 2018 is obtained in this study by means of PSI and GPS technology, both of which have suitable consistency in obtaining the vertical deformation of the surface (Figure 4). Chaoyang and parts of Tongzhou, which are situated in the east of the Beijing Plain, are residential areas severely affected by land subsidence. Several major land subsidence centers are connected together, and the subsidence center velocity has been above $100 \mathrm{~mm} / \mathrm{y}$ for many years. In 2014, the maximum land subsidence rate reached $143.20 \mathrm{~mm} / \mathrm{y}$. From 2015 to 2017, the maximum subsidence rate in the eastern part of the plain area exceeded $135.00 \mathrm{~mm} / \mathrm{y}$. The land subsidence in the eastern region, however, slowed down significantly in 2018, and the maximum subsidence rate declined to $118.60 \mathrm{~mm} / \mathrm{y}$. The distribution of land subsidence in the northern part of the plain was scattered, and the areas with severe subsidence were mainly distributed in the northern part of Haidian, southern Changping, and part of Shunyi. The rate of land subsidence in the northern plain began to decrease in 2016, along with the land subsidence area. This phenomenon became increasingly more obvious from 2017 to 2018. The land subsidence rate in the northern part of Haidian District was $60 \sim 90 \mathrm{~mm} / \mathrm{y}$ from 2013 to 2015 , and the subsidence rate fell to $30 \sim 50 \mathrm{~mm} / \mathrm{y}$ in 2018 . In the southern part of Changping, the land subsidence rate was $60 \sim 100 \mathrm{~mm} / \mathrm{y}$ from 2013 to 2015, and the subsidence rate declined to $40 \sim 50 \mathrm{~mm} / \mathrm{y}$ in 2018. In some areas of Shunyi, the land subsidence rate was $40 \sim 50 \mathrm{~mm} / \mathrm{y}$ from 2013 to 2015 and decreased to $20 \sim 30 \mathrm{~mm} / \mathrm{y}$ in 2018. The areas with severe land subsidence in the southern part of the plain were mainly located in Daxing District, especially the area bordering Hebei Province. The subsidence rate was always maintained at 50 70 mm/y from 2013 to 2018 (Figure 4). 

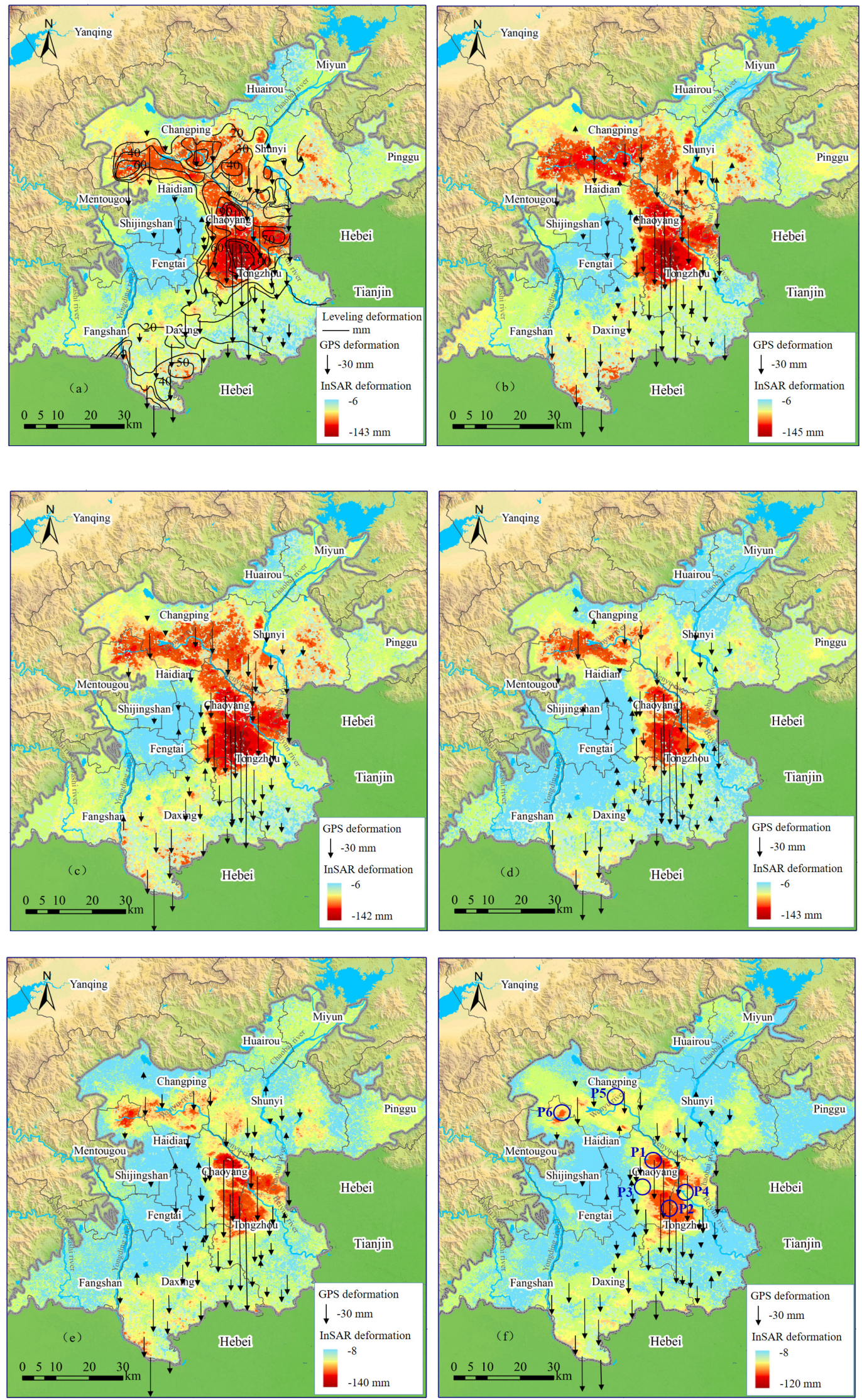

Figure 4. The distribution characteristics of land subsidence in Beijing Plain (2013 2018). (a) 2013. (b) 2014. (c) 2015. (d) 2016. (e) 2017. (f) 2018. 
From 2013 to 2018, the average subsidence rate, together with the area and volume of severe subsidence (subsidence rate greater than $50 \mathrm{~mm} / \mathrm{y}$ ), showed a decreasing trend in the Beijing Plain. The average land subsidence rate decreased from $21.7 \mathrm{~mm} / \mathrm{y}$ in 2013 to $13.32 \mathrm{~mm} / \mathrm{y}$ in 2018 and with a decrease of $8.38 \mathrm{~mm} / \mathrm{y}$ (Figure 5a). The area of severe subsidence reduced from $572 \mathrm{~km}^{2}$ in 2013 to $383 \mathrm{~km}^{2}$ in 2018, with a decrease of $189 \mathrm{~km}^{2}$ (Figure 5a). The total volume of the subsided area reduced from $13210 \times 104 \mathrm{~m}^{3}$ in 2013 to $8120 \times 10^{4} \mathrm{~m}^{3}$ in 2018, with a decrease of $5090 \times 10^{4} \mathrm{~m}^{3}$ (Figure $5 \mathrm{~b}$ ).

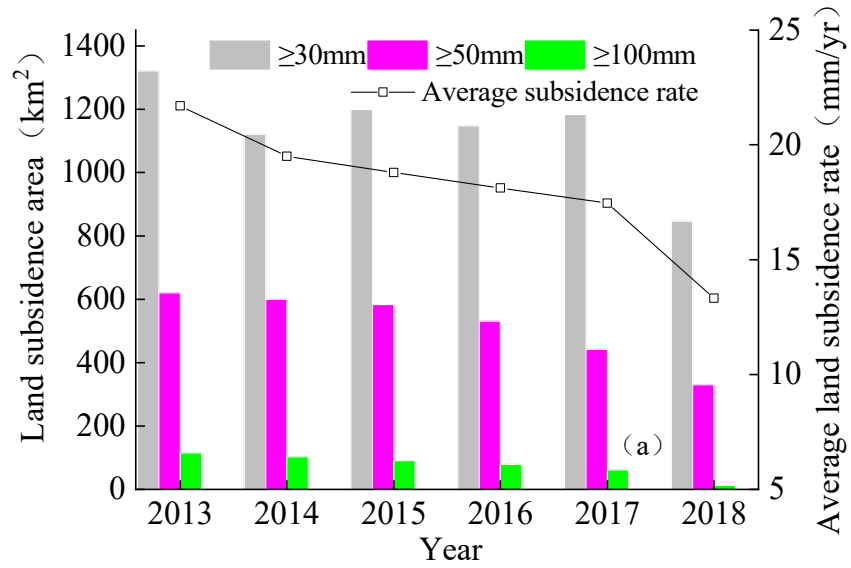

(a)

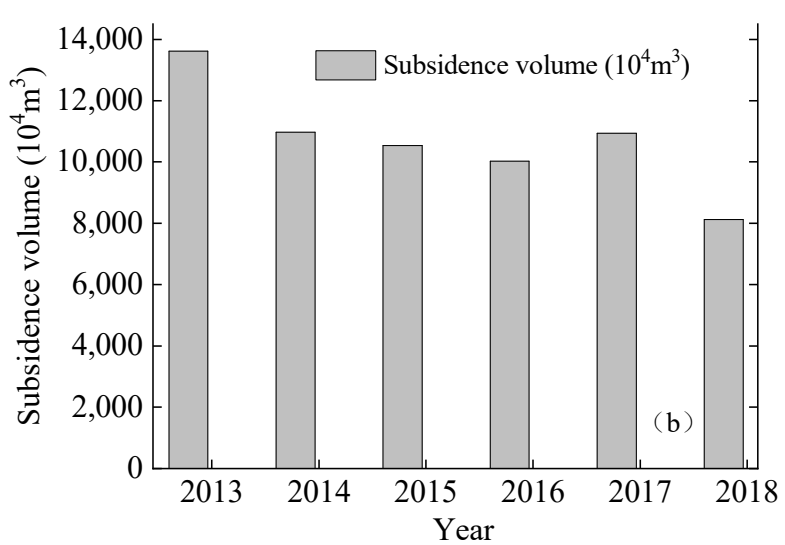

(b)

Figure 5. Statistics graphs of average subsidence rate, subsidence area, and volume (2013 2018). (a) Statistics of average land subsidence rate and subsidence area from 2013 to 2018. (b) Statistics of land subsidence volume from 2013 to 2018.

\subsubsection{Cumulative Land Subsidence Characteristics}

The cumulative subsidence curves of six typical land subsidence centers (P1 P6) from 2013 to 2018 are obtained in this study by means of three methods, including PSI, GPS, and leveling. The locations are shown in Figure 4f. Now that the selected PS point and the GPSleveling integrated point cannot completely overlap, the GPS-leveling integrated point is taken as the center, with the adjacent PS points selected within a radius of $100 \mathrm{~m}$ for analysis. As shown in the results, the cumulative land subsidence of each subsidence center is gradually increasing with time. From 2013 to 2018, the maximum accumulated subsidence at $\mathrm{P} 1$ reached $816.77 \mathrm{~mm}$, which was the area with the largest accumulated land subsidence in Beijing. The maximum accumulated settlement at P2 was $792.10 \mathrm{~mm}$, and the maximum accumulated land subsidence at P3 P6 749.00, 627.00, 456.00, and $437.00 \mathrm{~mm}$, respectively. Through comparative analysis of PSI, GPS, and leveling measurement results, it is found that from 2013 to 2018, the deviation between the cumulative land subsidence obtained by PSI and the leveling measurement result was between 4 and $30 \mathrm{~mm}$; the deviation between the cumulative land subsidence obtained by GPS and the leveling measurement result was between 5 and $50 \mathrm{~mm}$, and the cumulative land subsidence obtained by these three methods had suitable consistency in the development trend (Figure 6). 


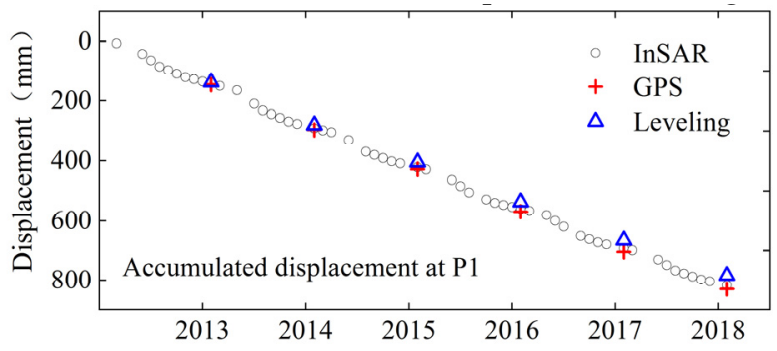

(a)

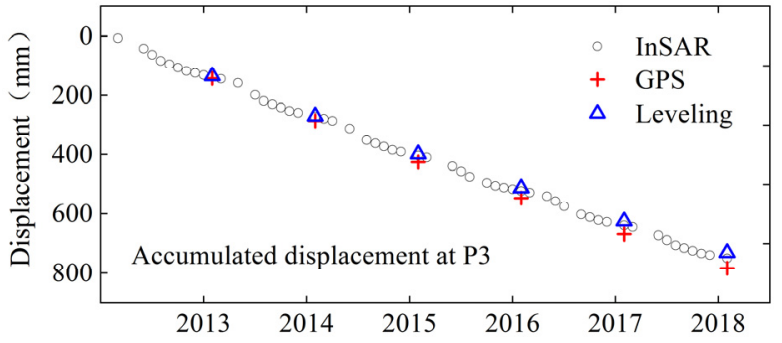

(c)

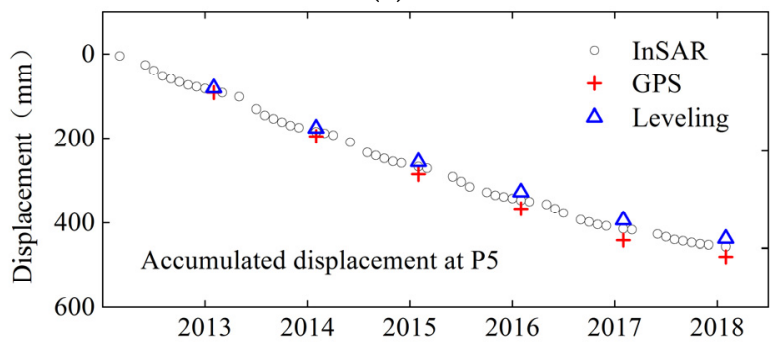

(e)

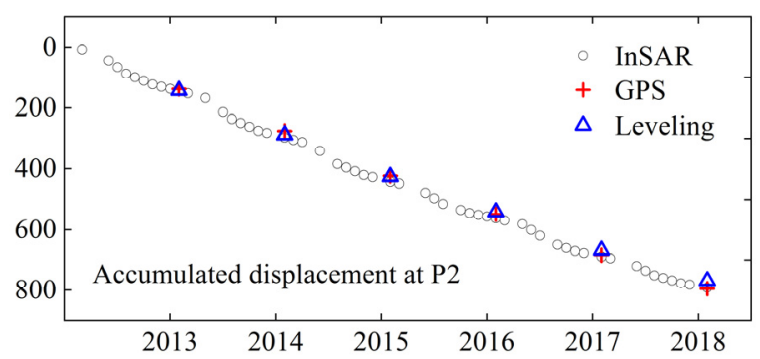

(b)

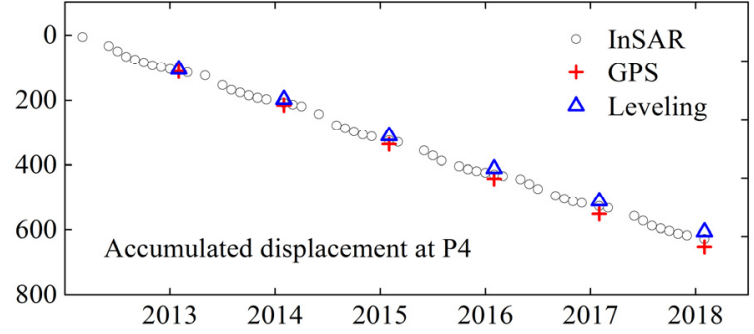

(d)

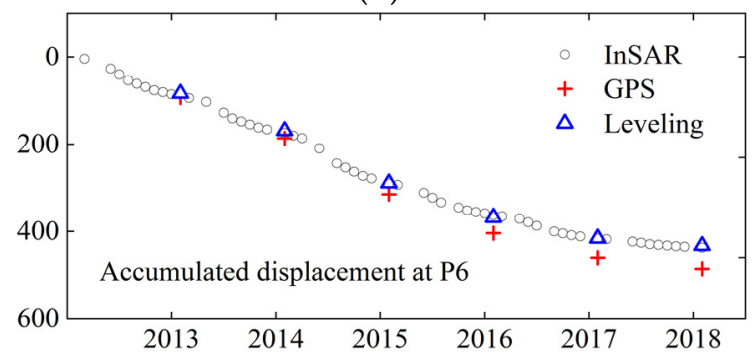

(f)

Figure 6. Comparison of accumulated land subsidence obtained by PSI, GPS, and leveling from 2013 to 2018. (a) Comparison result at P1. (b) Comparison result at P2. (c) Comparison result at P3. (d) Comparison result at P4. (e) Comparison result at P5. (f) Comparison result at P6.

\subsubsection{Verification Accuracy of PSI and GPS Vertical Deformation}

A total of 40 leveling points of 2017 are selected to validate InSAR and GPS vertical deformation results (Table 2). Through comparison, it is found that the InSAR and the leveling results show the same deformation characteristics. The difference range of them is between 2 and $8 \mathrm{~mm}$, the mean square error is $4.33 \mathrm{~mm}$, and there is a significant linear correlation, with an $\mathrm{R}^{2}$ of 0.983 (Figure 7). Meanwhile, by comparing the GPS measurement with the leveling results, it is found that the difference between more than $80 \%$ of GPS points and the leveling points is less than $10 \mathrm{~mm}$. Some points have a large mutual difference, the maximum of which is $15.80 \mathrm{~mm}$, the mean square error is $7.56 \mathrm{~mm}$, and the correlation coefficient $\left(\mathrm{R}^{2}\right)$ is 0.946 (Figure 7 ). The verification results suggest that the accuracy of InSAR and GPS measurement is reliable, and they can reflect in detail the vertical deformation and spatial distribution characteristics of land subsidence in the Beijing Plain.

Table 2. Comparison of PSI, GPS vertical deformation, and leveling measurement results.

\begin{tabular}{|c|c|c|c|c|c|c|c|c|c|c|c|}
\hline \multirow{2}{*}{$\begin{array}{l}\text { Benchmark } \\
\text { Number }\end{array}$} & \multicolumn{5}{|c|}{ Annual Land Subsidence(mm) } & \multirow{2}{*}{$\begin{array}{c}\text { Benchmark } \\
\text { Number }\end{array}$} & \multicolumn{5}{|c|}{ Annual Land Subsidence(mm) } \\
\hline & PSI & GPS & Leveling & $\begin{array}{c}\text { PSI- } \\
\text { Leveling }\end{array}$ & $\begin{array}{c}\text { GPS- } \\
\text { Leveling }\end{array}$ & & PSI & GPS & Leveling & $\begin{array}{c}\text { PSI- } \\
\text { Leveling }\end{array}$ & $\begin{array}{c}\text { GPS- } \\
\text { Leveling }\end{array}$ \\
\hline BJ001 & -42.5 & -46.2 & -38.4 & -4.1 & -7.8 & ВJ021 & -25.6 & -33.6 & -18.3 & -7.3 & -15.3 \\
\hline BJ002 & -38.0 & -40.0 & -32.0 & -6.0 & -8.0 & BJ022 & -18.3 & -22.9 & -15.2 & -3.1 & -7.7 \\
\hline BJ003 & -39.2 & -43.4 & -42.9 & 3.7 & -0.5 & BJ023 & 2.20 & -10.8 & -1.1 & 3.3 & -9.7 \\
\hline BJ004 & -18.0 & -30.0 & -21.0 & 3.0 & -9.0 & BJ024 & -45.0 & -40.2 & -52.2 & 7.2 & 12.0 \\
\hline BJ005 & -19.8 & -30.2 & -25.2 & 5.4 & -5.0 & BJ025 & 2.10 & -6.6 & -1.6 & 3.7 & -5.0 \\
\hline BJ006 & -32.2 & -25.1 & -37.8 & 5.6 & 12.7 & BJ026 & -32.5 & -40.3 & -25.1 & -7.4 & -15.2 \\
\hline BJ007 & -40.1 & -54.2 & -46.7 & 6.6 & -7.5 & BJ027 & -5.4 & -19.3 & -9.7 & 4.3 & -9.6 \\
\hline BJ008 & -15.3 & -19.1 & -18.3 & 3.0 & -0.8 & BJ028 & -24.0 & -32.4 & -20.0 & -4.0 & -12.4 \\
\hline
\end{tabular}


Table 2. Cont.

\begin{tabular}{|c|c|c|c|c|c|c|c|c|c|c|c|}
\hline \multirow{2}{*}{$\begin{array}{c}\text { Benchmark } \\
\text { Number }\end{array}$} & \multicolumn{5}{|c|}{ Annual Land Subsidence(mm) } & \multirow{2}{*}{$\begin{array}{c}\text { Benchmark } \\
\text { Number }\end{array}$} & \multicolumn{5}{|c|}{ Annual Land Subsidence(mm) } \\
\hline & PSI & GPS & Leveling & $\begin{array}{c}\text { PSI- } \\
\text { Leveling }\end{array}$ & $\begin{array}{c}\text { GPS- } \\
\text { Leveling }\end{array}$ & & PSI & GPS & Leveling & $\begin{array}{c}\text { PSI- } \\
\text { Leveling }\end{array}$ & $\begin{array}{c}\text { GPS- } \\
\text { Leveling }\end{array}$ \\
\hline BJ009 & -10.2 & -15.9 & -6.0 & -4.2 & -9.9 & BJ029 & -29.0 & -20.1 & -31.4 & 2.4 & 11.3 \\
\hline BJ010 & 3.5 & -1.7 & -4.8 & 8.3 & 3.1 & BJ030 & -135.3 & -124.2 & -129.2 & -6.1 & 5.0 \\
\hline BJ011 & -134.0 & -115.8 & -126.9 & -7.1 & 11.1 & BJ031 & -6.0 & -4.0 & -3.9 & -2.1 & -0.1 \\
\hline BJ012 & -26.0 & -37.3 & -34.0 & 8.0 & -3.3 & BJ032 & -16.9 & -5.8 & -11.5 & -5.4 & 5.7 \\
\hline BJ013 & -5.8 & -4.9 & -11.6 & 5.8 & 6.7 & BJ033 & 2.1 & -1.9 & -2.9 & 5.0 & 1.0 \\
\hline BJ014 & -19.8 & -32.1 & -16.3 & -3.5 & -15.8 & BJ034 & -36.2 & -28.2 & -33.9 & -2.3 & 5.7 \\
\hline BJ015 & -28.9 & -35.2 & -33.2 & 4.3 & -2.0 & BJ035 & -33.0 & -35.1 & -33.1 & 0.1 & -2.0 \\
\hline BJ016 & -6.9 & -19.2 & -10.2 & 3.3 & -9.0 & BJ036 & -30.0 & -33.3 & -32.9 & 2.9 & -0.4 \\
\hline BJ017 & -26.0 & -35.7 & -27.5 & 1.5 & -8.2 & BJ037 & -12.5 & -11.5 & -15.1 & 2.6 & 3.6 \\
\hline BJ018 & -6.2 & -9.3 & -3.5 & -2.7 & -5.8 & BJ038 & -119.4 & -118.1 & -118.4 & -1.0 & 0.3 \\
\hline BJ019 & -18.5 & -12.0 & -16.2 & -2.3 & 4.2 & BJ039 & -57.6 & -64.7 & -60.5 & 2.9 & -4.2 \\
\hline BJ020 & -36.4 & -23.6 & -31.0 & -5.4 & 7.4 & BJ040 & -8.3 & -5.2 & -9.5 & 1.2 & 4.3 \\
\hline
\end{tabular}

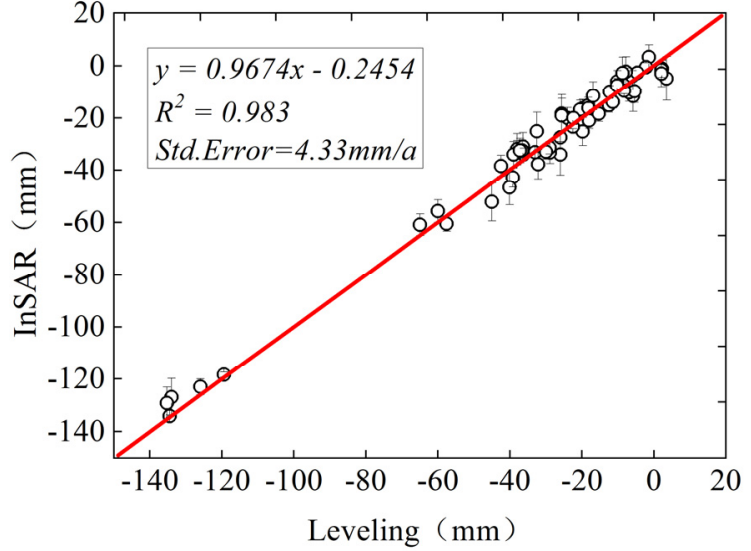

(a)

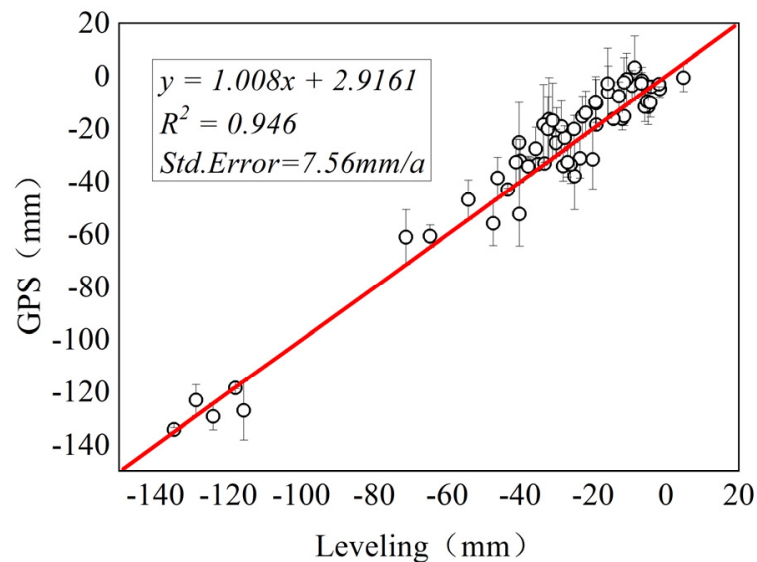

(b)

Figure 7. Comparison of time-series subsidence between PSI, GPS, and leveling. (a) Comparison of time-series subsidence between PSI and leveling. (b) Comparison of time-series subsidence between GPS and leveling.

\subsection{Horizontal Deformation}

4.2.1. Horizontal Velocity of GPS under the ITRF2005 Reference Frame

Figure 8 shows the distribution of GPS horizontal displacement field in the Beijing Plain during 2013 2015, 2016, 2017, and 2018 under the ITRF2005 framework. The results show that the trend of all GPS points under the ITRF2005 framework was basically the same. The overall movement direction was SE, with the dominant movement direction being NE112. $5^{\circ} \sim \mathrm{NE} 113.8^{\circ}$, reflecting the continuous deformation feature under a unified continental dynamic environment. The movement speed of each GPS point in the N direction is $-10.90 \sim-19.73 \mathrm{~mm} / \mathrm{y}$, and the average value is $-13.57 \mathrm{~mm} / \mathrm{y}$. The movement speed in the E direction was $27.12 \sim 36.19 \mathrm{~mm} / \mathrm{y}$, and the average value was $30.78 \mathrm{~mm} / \mathrm{y}$. The analysis results above are consistent with the overall crustal movement status of North China obtained by other scholars using GPS technology $[45,47]$. 

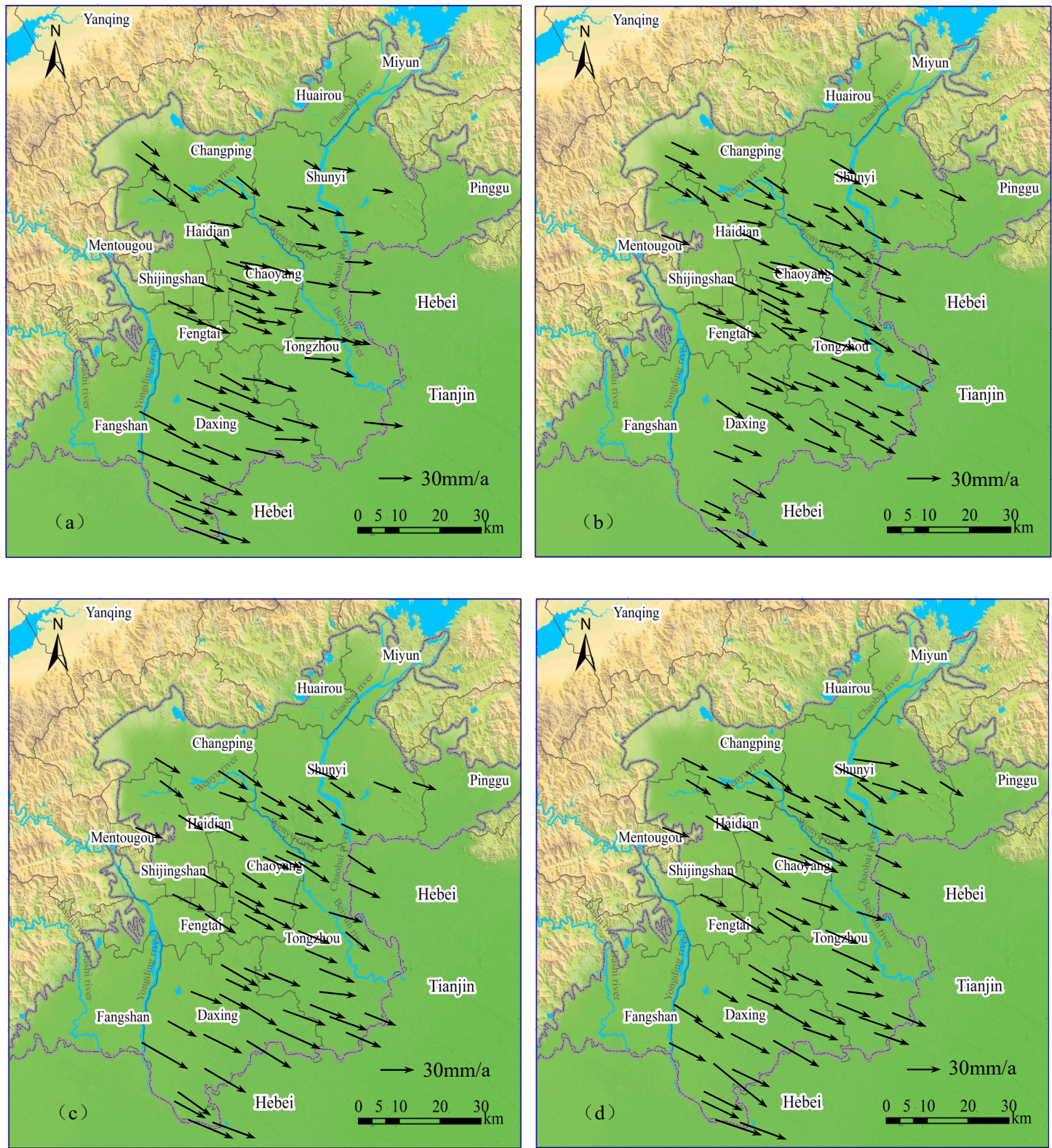

Figure 8. Horizontal velocity of GPS in Beijing Plain under ITRF2005 reference frame. (a) 2013 2015. (b) 2016. (c) 2017. (d) 2018 .

\subsubsection{Accuracy Analysis of GPS Horizontal Velocity}

Table 3 shows the horizontal velocity and internal accord accuracy of 40 GPS and level integration points and 6 CORS stations in 2017 under the ITRF2005 reference frame. According to the calculation results, it is shown that the error of the 40 GPS points in the velocity components of the E-W and S-N directions is basically between 2.00 and $5.00 \mathrm{~mm} / \mathrm{y}$; that of the 6 CORS stations in the velocity components of the E-W and S-N directions basically between 0.06 and $0.10 \mathrm{~mm} / \mathrm{y}$. The observation accuracy of the CORS stations is higher, which is mainly due to the better observation environment of the CORS stations and the longer time span of the observation data. 
Table 3. The horizontal velocity and accuracy of GPS in 2017 under the ITRF2005 reference frame.

\begin{tabular}{|c|c|c|c|c|c|c|c|c|c|}
\hline \multirow{2}{*}{$\begin{array}{l}\text { Benchmark } \\
\text { Number }\end{array}$} & \multicolumn{2}{|c|}{$\begin{array}{l}\text { Horizontal Velocity } \\
(\mathrm{mm} / \mathrm{y})\end{array}$} & \multicolumn{2}{|c|}{$\begin{array}{l}\text { Accuracy } \\
(\mathrm{mm} / \mathrm{y})\end{array}$} & \multirow{2}{*}{$\begin{array}{c}\text { Benchmark } \\
\text { Number }\end{array}$} & \multicolumn{2}{|c|}{$\begin{array}{l}\text { Horizontal Velocity } \\
(\mathrm{mm} / \mathrm{y})\end{array}$} & \multicolumn{2}{|c|}{$\begin{array}{l}\text { Accuracy } \\
(\mathrm{mm} / \mathrm{y})\end{array}$} \\
\hline & $\mathrm{V}_{\mathrm{E}}$ & $\mathrm{V}_{\mathrm{N}}$ & $\Delta_{\mathrm{E}}$ & $\Delta_{\mathrm{N}}$ & & $\mathrm{V}_{\mathrm{E}}$ & $\mathrm{V}_{\mathrm{N}}$ & $\Delta_{\mathrm{E}}$ & $\Delta_{\mathrm{N}}$ \\
\hline BJ001 & 28.82 & -14.67 & 3.70 & 4.30 & BJ024 & 30.36 & -18.86 & 4.00 & 3.50 \\
\hline BJ002 & 32.62 & -16.74 & 4.30 & 3.90 & BJ025 & 29.10 & -15.33 & 4.30 & 2.10 \\
\hline BJ003 & 28.29 & -10.72 & 2.80 & 3.80 & BJ026 & 31.51 & -12.90 & 4.30 & 2.80 \\
\hline BJ004 & 28.69 & -15.06 & 3.90 & 4.30 & BJ027 & 34.60 & -16.94 & 2.90 & 3.70 \\
\hline BJ005 & 27.59 & -11.27 & 2.40 & 4.70 & BJ028 & 27.69 & -15.77 & 3.70 & 5.00 \\
\hline BJ006 & 27.29 & -11.89 & 2.40 & 4.20 & BJ029 & 32.73 & -18.99 & 1.60 & 3.60 \\
\hline BJ007 & 29.48 & -12.29 & 4.00 & 3.10 & BJ030 & 30.76 & -13.90 & 4.70 & 3.20 \\
\hline BJ008 & 28.40 & -16.16 & 3.20 & 4.70 & BJ031 & 34.41 & -19.22 & 3.80 & 2.50 \\
\hline BJ009 & 30.92 & -11.44 & 4.80 & 3.40 & BJ032 & 32.53 & -16.18 & 4.90 & 3.70 \\
\hline BJ010 & 31.08 & -17.75 & 2.20 & 2.90 & BJ033 & 31.57 & -12.80 & 3.80 & 4.50 \\
\hline BJ011 & 31.76 & -11.58 & 2.30 & 3.80 & BJ034 & 34.99 & -16.64 & 4.30 & 3.60 \\
\hline BJ012 & 33.22 & -10.90 & 4.60 & 2.30 & BJ035 & 33.87 & -12.51 & 4.90 & 3.80 \\
\hline BJ013 & 32.65 & -13.54 & 3.90 & 4.20 & BJ036 & 31.53 & -11.90 & 4.40 & 2.80 \\
\hline BJ014 & 28.19 & -15.46 & 3.90 & 2.20 & BJ037 & 31.12 & -16.98 & 4.40 & 3.90 \\
\hline BJ015 & 28.14 & -18.91 & 4.70 & 2.30 & BJ038 & 33.85 & -12.27 & 4.80 & 2.40 \\
\hline BJ016 & 32.39 & -16.05 & 4.40 & 3.20 & BJ039 & 28.82 & -15.34 & 3.20 & 4.40 \\
\hline BJ017 & 29.20 & -11.65 & 4.90 & 4.30 & BJ040 & 32.83 & -16.66 & 2.70 & 3.60 \\
\hline BJ018 & 28.36 & -15.52 & 4.80 & 4.60 & ZJWZ & 28.58 & -16.19 & 0.07 & 0.09 \\
\hline BJ019 & 28.94 & -12.81 & 2.90 & 4.60 & NLSH & 27.80 & -12.78 & 0.06 & 0.08 \\
\hline BJ020 & 32.36 & -14.65 & 4.60 & 2.60 & CHAO & 28.92 & -18.57 & 0.08 & 0.10 \\
\hline BJ021 & 32.63 & -15.41 & 3.90 & 4.30 & DSQI & 34.12 & -17.77 & 0.07 & 0.09 \\
\hline BJ022 & 31.40 & -13.40 & 3.70 & 4.00 & YUFA & 27.32 & -12.05 & 0.07 & 0.09 \\
\hline BJ023 & 29.59 & -18.49 & 2.80 & 4.90 & $\mathrm{CHPN}$ & 30.10 & -11.25 & 0.07 & 0.09 \\
\hline
\end{tabular}

\subsubsection{Horizontal Velocity of GPS under the Eurasian Reference Frame}

The horizontal velocity under the ITRF2005 reference framework reflects the overall movement situation of the Beijing Plain under the global framework. Compared to global reference datums, the coordinate and velocity under this framework can be regarded as the absolute coordinate and velocity. Since the velocity under the framework contains the horizontal movement velocity of the entire plate and the horizontal strain within the region, the overall horizontal component is relatively large, which masks the relatively small deformation difference within the region. Therefore, the Eurasian plate velocity from the velocity under the ITRF frame needs to be deducted so as to obtain the internal horizontal velocity of all GPS points under the Eurasian reference frame. In the calculation process, three bedrock CORS stations, BJFS, BJSH, and JIXN, are selected as the stable reference datum, and the parameter values of the Euler vector in the Eurasian plate refer to the NNR-NUVEL1A model (longitude $-112.27^{\circ}$, latitude $50.61^{\circ}$, angular velocity $0.23^{\circ} / \mathrm{Ma}$ ).

As shown in Figure 9, the GPS points take the Eurasian plate as a reference, the horizontal velocity within the area is significantly reducing, and the inconsistency changes between the points are obvious; the movement rate and direction of each point show a certain disorder not manifesting the overall trend movement. From 2013 to 2015, 42\% of GPS points moved horizontally in the SE direction, with a movement rate of $1.45 \sim 20.10 \mathrm{~mm} / \mathrm{y}$; $35 \%$ of GPS points in the NE direction, with a movement rate of $1.32 \sim 18.96 \mathrm{~mm} / \mathrm{y} ; 10 \%$ of GPS points in the SW direction, with a movement rate of $1.35 \sim 9.52 \mathrm{~mm} / \mathrm{y}$; and $13 \%$ of the GPS points in the NW direction, with a movement rate of $0.85 \sim 9.24 \mathrm{~mm} / \mathrm{y}$. The spatial distribution was roughly bounded by the northern line of the Daxing District, with a tensile deformation characteristic, and with a trend of NE to SW rotation in the northern plain area (Figure 9a). In 2016, 65\% of GPS points moved horizontally in the SE direction, especially in the southern part of the plain area, with a movement rate of $1.35 \sim 18.25 \mathrm{~mm} / \mathrm{y}$. In Chaoyang, northern Tongzhou, and parts of Shunyi, the horizontal deformation was complex, some of which was indicative of tension and compression (Figure 9b). In 2017 
and 2018, as shown in GPS observation results, the southern plain area mainly moved in the E and SE directions, and in Chaoyang, the northern part of Tongzhou, the southern Changping as well as part of Shunyi, the horizontal movement velocity was relatively large, without obvious directionality. The horizontal deformation, especially at the junction of several major active faults, was very complicated (Figure 9c,d). These areas often had severe land subsidence.
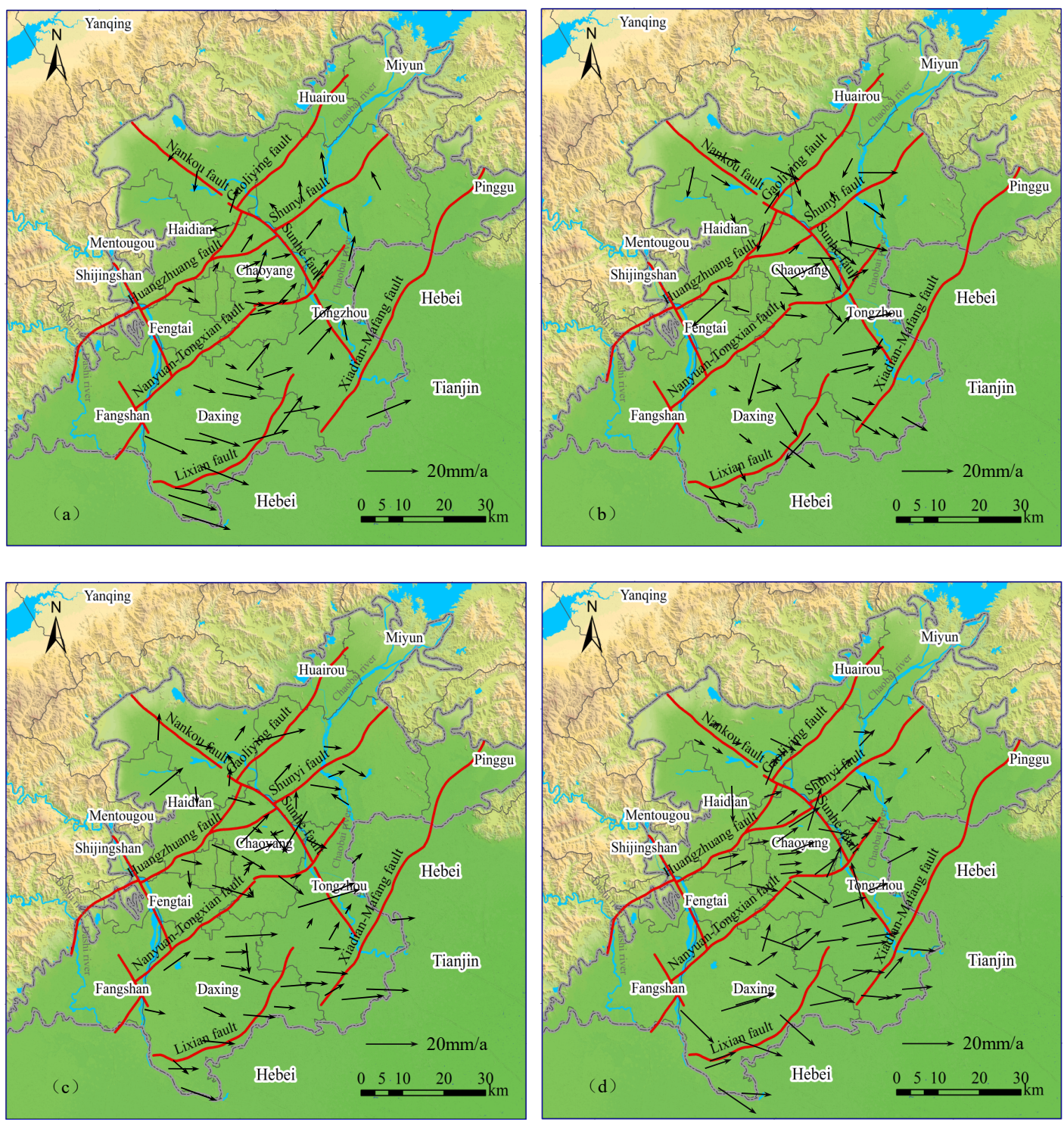

Figure 9. Horizontal velocity of GPS in the Beijing Plain under the Eurasian Reference Frame. (a) 2013 2015. (b) 2016. (c) 2017. (d) 2018.

\section{Discussion}

\subsection{The Control Effect of Base Structure on 3D Deformation}

\subsubsection{The Control Effect of Basement Structure on Vertical Deformation}

By combining the land subsidence obtained by PSI with the main active faults, it is found that the distribution of land subsidence is structurally controlled in Beijing Plain. The subsided areas, part of which coincide with the Quaternary depression at the junction of several major active faults, are divided by several major active faults, which control the development of land subsidence (Figure 10a). 


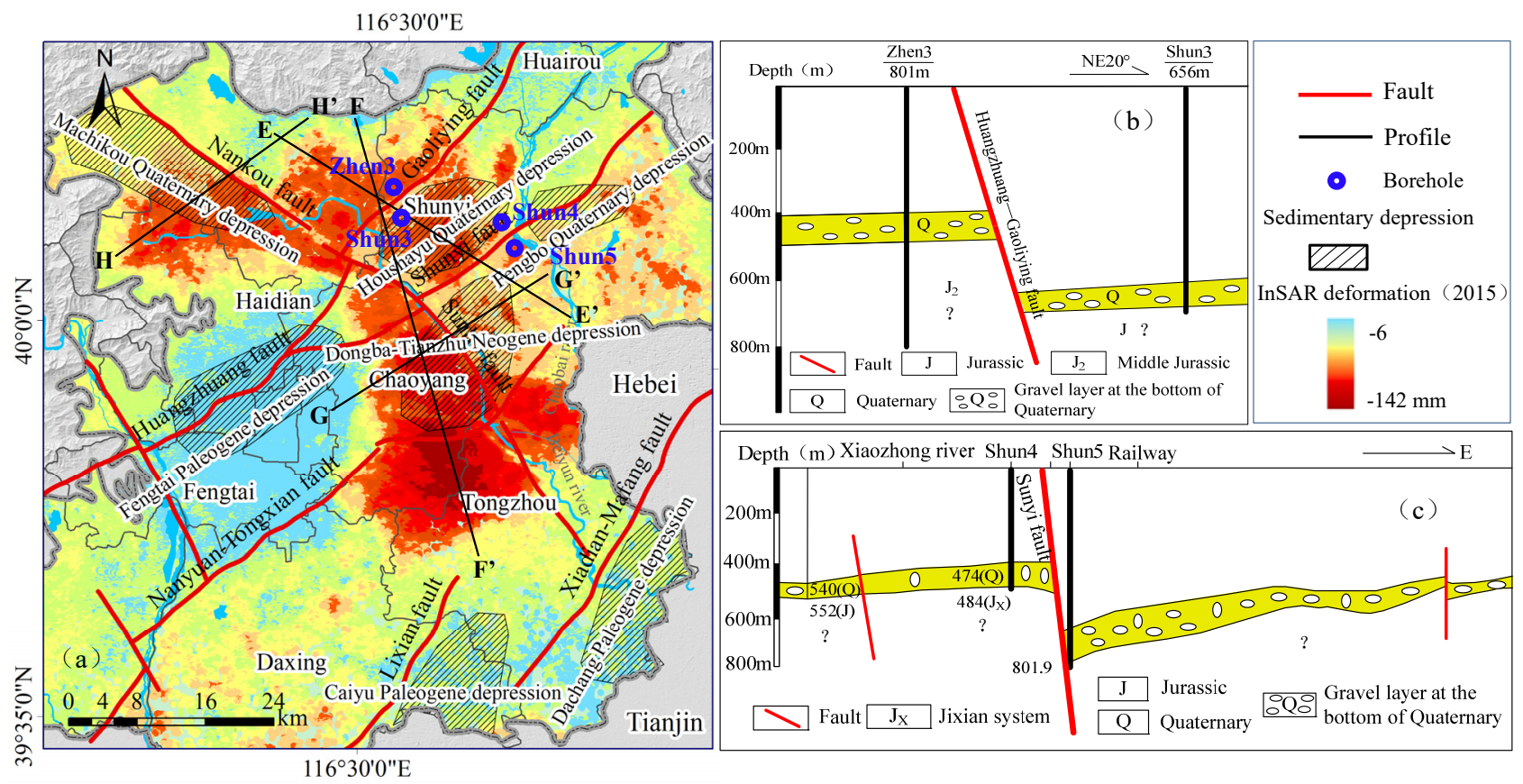

Figure 10. Basement structure and land subsidence distribution, and borehole profiles on both sides of the fault. (a) Main active faults and distribution of land subsidence in 2015. (b) Drilling section on both sides of Huangzhuang-Gaoliying fault. (c) Drilling profile on both sides of the Shunyi fault.

The NW-SE striking Nankou-Sunhe fault runs through the entire Beijing Plain, dividing the main subsidence area into two parts: the northeastern and the southwestern. The subsidence area in the northern part of Haidian and the southern part of Changping is mainly controlled by the northwestern section of the Nankou-Sunhe fault. The location of Shangzhuang's subsided area in the north of Haidian is consistent with the Machikou Quaternary depression. The subsided area in the northern part of Changping is affected by both the NE-SW striking Huangzhuang-Gaoliying fault and the NW-SE striking NankouSunhe fault. The distribution of subsided area in Shunyi is affected by both the NE-SW striking Shunyi fault and the northern section of NE-SW striking Huangzhuang-Gaoliying fault. The subsided area is mainly distributed in the Houshayu Quaternary Depression, which is bounded by Huangzhuang-Gaoliying and Shunyi fault. (Figure 10a).

The control effect of the fault on the land subsidence is mainly revealed by the offset of the fault and the different thickness of the Quaternary beds on both sides of the fault. According to the data from the Zhen 3 and Shun 3 drill holes of the upper and lower plates of the Huangzhuang-Gaoliying fault, respectively, the Zhen 3 hole in the northwestern part of the fault passes through the loose accumulation layer at $430 \mathrm{~m}$ to expose andesite, while the Shun 3 hole in the southeast plate only exposes the tuffaceous breccia at $645 \mathrm{~m}$. Due to the influence of the early activities of the fault, the same sedimentary strata on both sides of the fault differed by more than 200 meters. (Figure 10b). According to the data from the Shun 4 and Shun 5 drill holes of the upper and lower plates of the Shunyi fault, respectively, the Shun 4 hole in the northwestern part of the fault passes through the loose accumulation layer at $474 \mathrm{~m}$ to expose dolomite, whereas no pre-Cenozoic bedrock has been found at a depth of $800 \mathrm{~m}$ in the Shun 5 hole on the southeast side of the fault. The same sedimentary strata on both sides of the fault differed by more than 200 meters. (Figure 10c). Meanwhile, the spatial distribution of land subsidence in Chaoyang and parts of Tongzhou are controlled by the southeast section of the Nankou-Sunhe fault.

It can be seen that the distribution and development trend of the main land subsidence areas in the Beijing Plain has an obvious corresponding relationship with the strike of active faults, and the structural control effect is very obvious. At present, the land subsidence in some areas has crossed the fault control and is directed parallel to the fault. 
Four typical land subsidence profile lines E-E', F-F', G-G', and H-H' are drawn through the active faults in the paper, the positions of which are shown in Figure 10a. Section E-E' passes through the northern section of the Huangzhuang-Gaoliying fault and the Shunyi fault. At the Huangzhuang-Gaoliying fault, the maximum differential land subsidence is $26.41 \mathrm{~mm} / \mathrm{y}$, and the maximum deformation gradient is $21.89 \mathrm{~mm} / \mathrm{km}$. At the Shunyi fault, the maximum differential land subsidence is $50.25 \mathrm{~mm} / \mathrm{y}$, and the maximum deformation gradient is $28.12 \mathrm{~mm} / \mathrm{km}$ (Figure 11a). Section F-F' passes through the HuangzhuangGaoliying fault, Nankou-Sunhe fault, Shunyi fault, and Nanyuan-Tongxian fault. At the Huangzhuang-Gaoliying fault, the maximum differential land subsidence is $28.23 \mathrm{~mm} / \mathrm{y}$, and the maximum deformation gradient is $16.50 \mathrm{~mm} / \mathrm{km}$. At the Nankou-Sunhe fault, the maximum differential land subsidence is $37.61 \mathrm{~mm} / \mathrm{y}$, and the maximum deformation gradient is $16.58 \mathrm{~mm} / \mathrm{km}$. At the Shunyi fault, the maximum differential land subsidence is $37.30 \mathrm{~mm} / \mathrm{y}$, and the maximum deformation gradient is $18.32 \mathrm{~mm} / \mathrm{km}$. At the NanyuanTongxian fault, the maximum differential land subsidence is $94.44 \mathrm{~mm} / \mathrm{y}$, and the maximum deformation gradient reaches $46.24 \mathrm{~mm} / \mathrm{km}$ (Figure 11b). Section G-G' passes through the Nankou-Sunhe fault. The maximum differential land subsidence is $87.84 \mathrm{~mm} / \mathrm{y}$, and the maximum deformation gradient reaches $65.81 \mathrm{~mm} / \mathrm{km}$ (Figure 11c). Section $\mathrm{H}-\mathrm{H}^{\prime}$ passes through the Nankou-Sunhe fault, the maximum differential land subsidence is $55.66 \mathrm{~mm} / \mathrm{y}$, and the maximum deformation gradient is $18.31 \mathrm{~mm} / \mathrm{km}$ (Figure 11d). Through the analysis above, it can be known that in the areas where active faults pass through, the land subsidence profile shows obvious transitions or sudden changes, and the uneven settlement on both sides of the fault is very obvious. This is mainly due to the control effect of the basement structure.
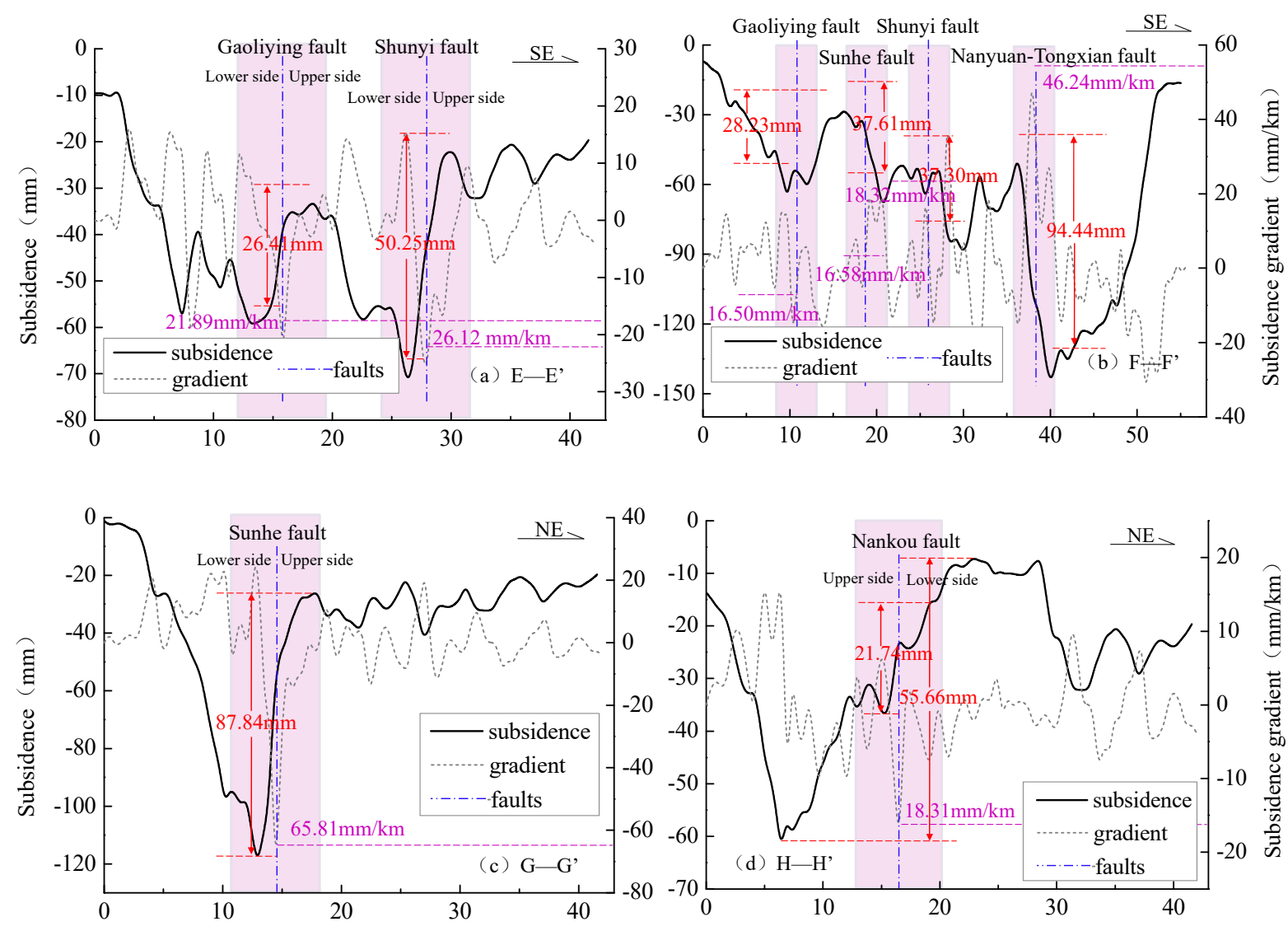

Figure 11. Differential land subsidence characteristics and deformation gradients on both sides of the fault. (a) Section E-E'. (b) Section F-F'. (c) Section G-G'. (d) Section H-H'. 


\subsubsection{The Control Effect of Basement Structure on Horizontal Deformation}

The average horizontal velocity of GPS points was obtained by calculating the horizontal velocity of GPS points in the Eurasian reference frame from 2013 to 2018. The Kriging method was used to perform spatial interpolation of GPS points in the E-W direction and S-N direction to obtain continuous horizontal deformation of the surface (Figure 12). Figure 12a shows that the maximum deformation in the E direction was $14.5 \mathrm{~mm} / \mathrm{y}$, the maximum deformation in the $\mathrm{W}$ direction was $6.5 \mathrm{~mm} / \mathrm{y}$, and the deformation in the $\mathrm{E}$ direction was greater than the $\mathrm{W}$ direction. The distribution of the horizontal deformation in the E-W direction was controlled by the Nankou-Sunhe fault. The S-W side of the fault was dominated by E directional movement, and the N-E side was dominated by W directional movement. The surface on both sides of the fault showed a tendency to move toward each other, especially at the junction of Chaoyang and Shunyi. In the central part of Tongzhou, especially at the intersection of the Nankou-Sunhe fault and Xiadian-Mafang fault, both sides of the fault also showed the characteristics of moving toward each other. Some GPS points at the junction of Daxing and Hebei Province moved in W direction, and other areas mainly moved in E direction (Figure 12a).
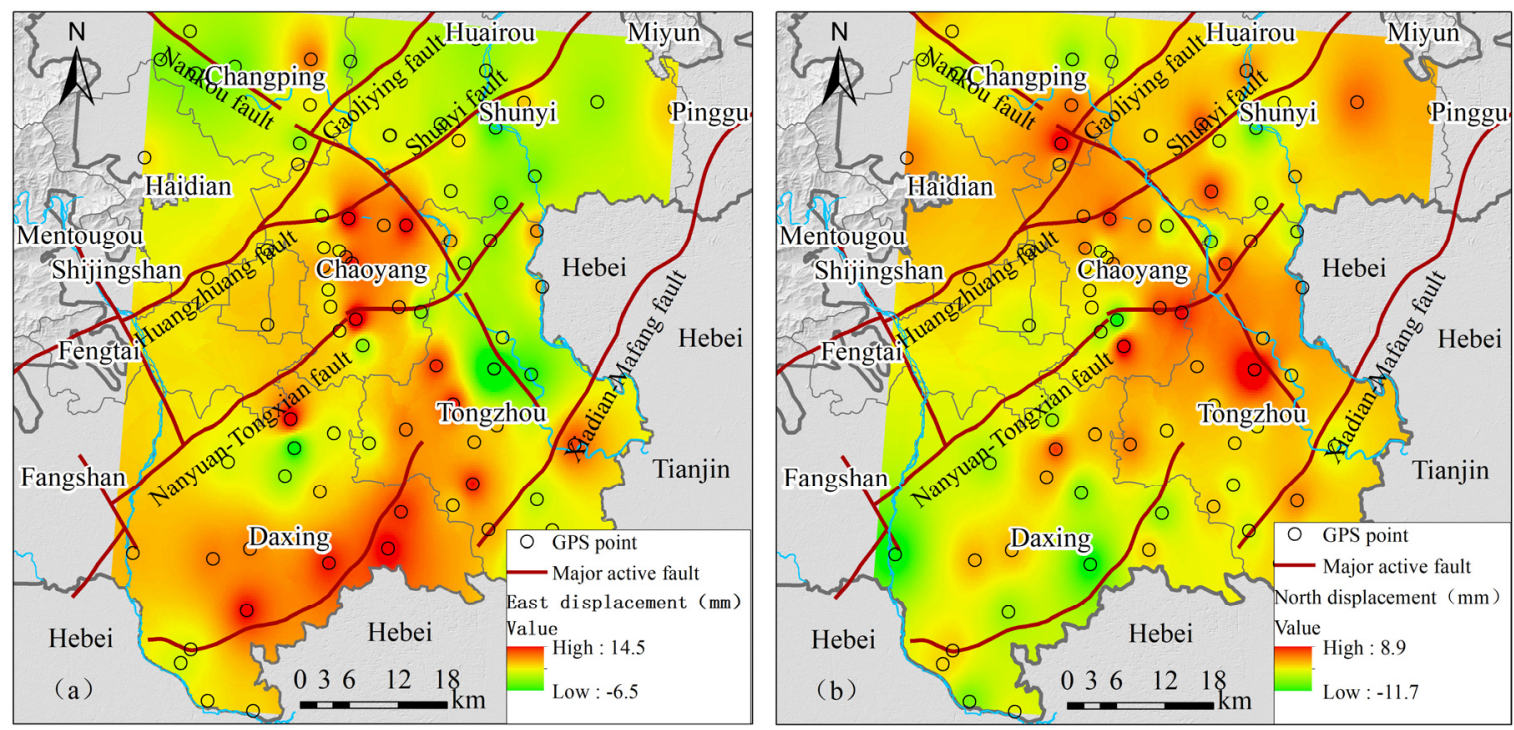

Figure 12. The main faults and the horizontal velocity obtained by GPS interpolation under the Eurasian Reference Frame (2013 2018). (a) E-W deformation. (b) S-N deformation.

Figure $12 \mathrm{~b}$ shows that the maximum deformation in the $\mathrm{N}$ direction was $8.9 \mathrm{~mm} / \mathrm{y}$, the maximum deformation in the $\mathrm{S}$ direction was $11.7 \mathrm{~mm} / \mathrm{y}$, and the deformation in the $\mathrm{S}$ direction was greater than the $\mathrm{N}$ direction. In the northern section of the HuangzhuangGaoliying fault, the northern area was dominated by the $\mathrm{S}$ direction movement, and the southern area was dominated by the $\mathrm{N}$ direction movement. The surface on both sides of the fault showed a tendency to move toward each other. Near the Shunyi fault, the northern area was dominated by the $\mathrm{N}$ directional movement, and the southern area by the S direction movement. Near the Nanyuan-Tongxian Fault, the northern area was dominated by the $\mathrm{S}$ direction movement, while the southern area had a trend of the $\mathrm{N}$ direction movement (Figure 12b). This shows that the horizontal deformation of the ground surface also had obvious structural control characteristics. It should be noted that the GPS points were evenly distributed in the plain, and some monitoring points were far away from the fault. The horizontal deformation obtained by Kriging interpolation cannot represent the deformation characteristics of the fault itself. 


\subsection{Influence of Groundwater Exploitation on 3D Deformation}

\subsubsection{Influence of Groundwater Exploitation on Land Subsidence}

According to previous studies, there is a clear correspondence between the development of land subsidence and the history of groundwater exploitation in the Beijing Plain. Excessive exploitation of groundwater is the main cause of ground subsidence in Beijing $[8,9,28]$. In this paper, the water level of different aquifers and the land subsidence velocity in 2017 are selected for analysis (Figure 13). The northern and western of the plain are located in the upper part of the alluvial fan, the stratum, which is mainly a single gravel layer structure and where the groundwater is mainly unconfined water, and the water table is generally at a relatively high level. Even if there is a groundwater-level funnel in these areas, it is not easy to cause land subsidence. For example, in the Miyun-Huairou-Shunyi groundwater-level funnel, the land subsidence is not obvious (Figure 13a). However, in the middle and lower parts of the plain, such as Chaoyang and Tongzhou, the stratum in these areas is an interactive structure of the cohesive soil layer and the sand layer, with the former being the main layer. When the groundwater-level funnel appears, the obvious land subsidence will result. Before the year 2000, the agricultural water exploitation layer was mainly concentrated in 50 100 m, and the industrial and domestic water exploitation layers in 100 180 m. The extraction amount of deep confined water from 180 to $300 \mathrm{~m}$ was very small, and the confined water with a roof depth of more than $300 \mathrm{~m}$ was not exploited. After 2000, due to the continuous decline of the shallow water table and the deterioration of water quality, the groundwater exploitation gradually developed to the deep layer. At the same time, groundwater exploitation has changed from unfined water or shallow confined water to medium-deep and deep confined water. Figure 13c,d illustrate that the groundwater-level funnel of the second confined aquifer (top and bottom buried depth of $100 \sim 180 \mathrm{~m}$ ) and the third confined aquifer (top and bottom buried depth of 180 300 m) is the most consistent with the land subsidence funnel. This is consistent with the current main mining layer of groundwater in Beijing and is the main layer where land subsidence occurs.

Ten extensometers and six groundwater wells have been constructed in the Tianzhu monitoring station to respectively monitor soil deformation and water table changes in aquifers at different depths. The location of the Tianzhu station is shown in Figure 1, and the monitoring layer depth of extensometers and wells is shown in Figure 14a. It can be seen in Figure 14b-d that the confined water level of each layer showed a continuous downward trend from 2004 to 2018. During the whole year, the groundwater level was characteristic of seasonal fluctuation. With the decline of the groundwater level, the compression of each soil layer continued to increase. In contrast, with the rise of the groundwater level, the soil layer rebounded, or the amount of compression slowed down.

The extensometer F3-8 monitoring layer was $48.5 \sim 64.5 \mathrm{~m}$, and the lithology was mainly fine sand and coarse sand. The average annual groundwater level dropped from $-4.58 \mathrm{~m}$ in 2005 to $-8.73 \mathrm{~m}$ in 2016 , with a drop of $4.15 \mathrm{~m}$. The extensometer F3-8 was compressed by $4.53 \mathrm{~mm}$ cumulatively. The groundwater level gradually began to increase in 2017, and the average annual water level rose to $-7.16 \mathrm{~m}$ in 2018, with an increase of $1.57 \mathrm{~m}$. The corresponding layered extensometer F3-8 rebounded by $0.31 \mathrm{~mm}$. During a period of a year, the sand layer showed an almost synchronous compression or rebound with the decline or rise of the groundwater level. The soil layer was mainly characterized by elastic deformation (Figure 14b). 

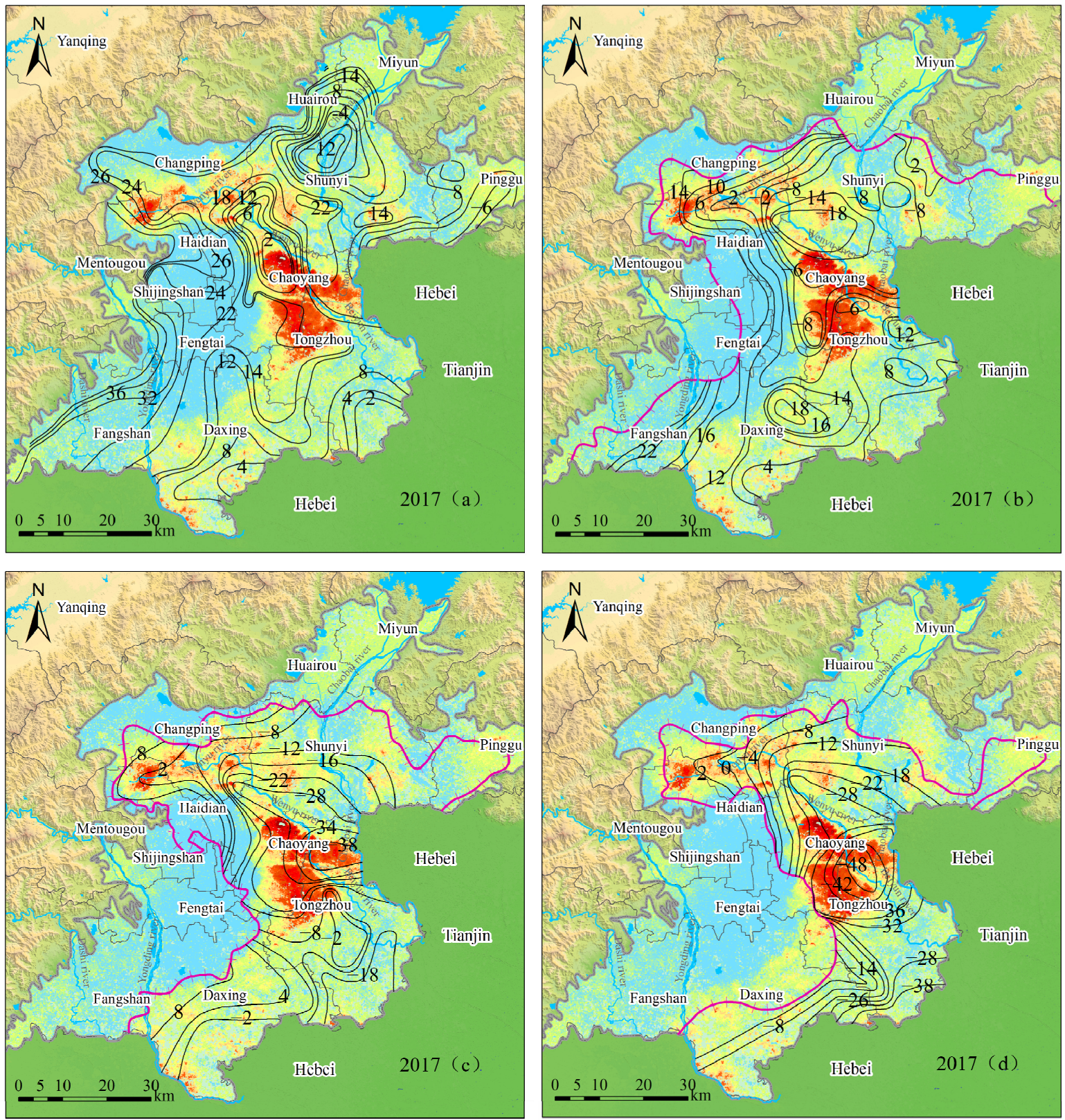

$+1+$ Different aquifer boundary

Water table elevation of different aquifers 8

-140 Deformation ( $\mathrm{mm}$ )

Figure 13. Land subsidence and water table elevation of different aquifers (2017). (a) Unconfined aquifer. (b) First confined aquifer. (c) Second confined aquifer. (d) Third confined aquifer.

The extensometer F3-6 monitoring layer dominated by a silty clay layer was $82.3 \sim 102.0 \mathrm{~m}$, containing a thin layer of fine sand with a thickness of $3.5 \mathrm{~m}$. The average annual groundwater level dropped from $-4.29 \mathrm{~m}$ in 2005 to $-12.29 \mathrm{~m}$ in 2018 , with a drop of $8.0 \mathrm{~m}$. The extensometer F3-6 was compressed by $25.49 \mathrm{~mm}$ cumulatively. With the water level of the aquifer cyclically rising and dropping, the decline of the water level was more than its increase in each cycle, and the water lever had a trend of falling on the whole. Correspondingly, the soil layer was also subjected to loading and unloading, with the stress increasing each time. The effective stress on the soil layer increased continuously, and the soil layer was compressed continuously. It was only in 2008 2009, and in 2018 that the soil layer rebounded slightly. Moreover, the soil layer was mainly characterized by plastic deformation (Figure 14c). 
The extensometer F3-4 monitoring layer, which was $117.0 \mathrm{~m} \sim 148.5 \mathrm{~m}$, was dominated by a fined sand layer containing a thin layer of silt with a thickness of $5.0 \mathrm{~m}$. Before June 2018, in each cycle, the decline of the water level was more than the increase of it, with the overall trend downward. The maximum water-level drop was $15.00 \mathrm{~m}$. This showed that the effective stress on the soil layer increased continuously, and the soil layer was compressed rapidly. After June 2018, the water level rose significantly, with the compression rate of the soil layer slowing down, but the compression still had a continuous increase, and the soil layer was mainly characterized by plastic deformation (Figure 14d).

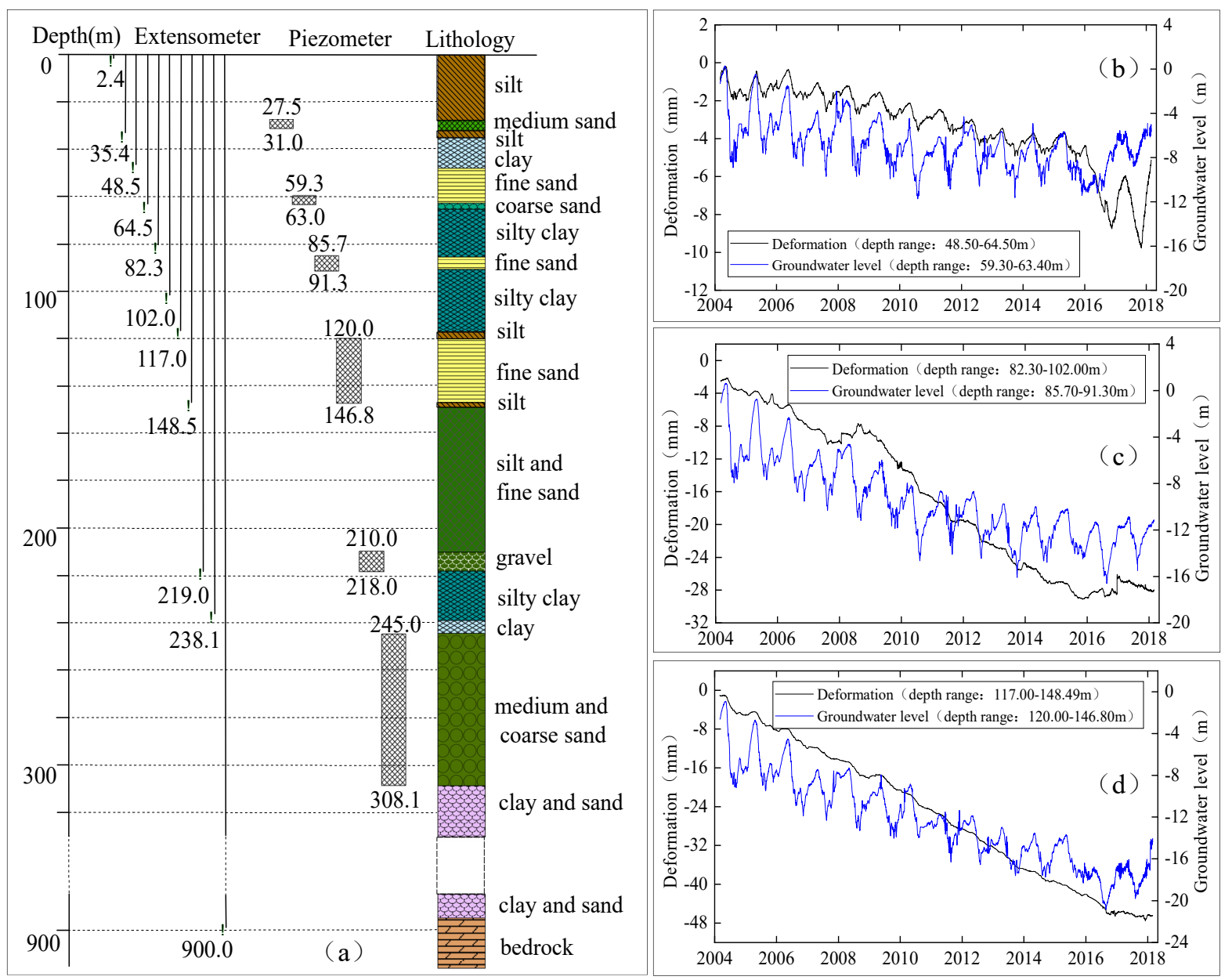

Figure 14. Schematic description of the borehole extensometer and groundwater well at Tianzhu station. The relationship between groundwater and land subsidence. (a) Schematic description of the borehole extensometer and groundwater well at Tianzhu. The lithological column is provided together with the depth of deformation. (b) The relationship between groundwater and land subsidence at F3-8. (c) The relationship between groundwater and land subsidence at F3-6. (d) The relationship between groundwater and land subsidence at F3-4.

\subsubsection{Influence of Groundwater Exploitation on Horizontal Deformation}

As shown in previous studies, the aquifer did not keep still during the process of groundwater extraction, the particle skeleton of which was dynamic and moving, but the movement velocity of which was lower than that of water. Whether the aquifer underwent vertical compaction or vertical deformation, the horizontal deformation of the aquifer always kept company with the pumping process [30,33-35]. With the monitoring results of 2017 taken as an example, the horizontal deformation under the Eurasian reference frame is analyzed with the land subsidence and the water level of different aquifers (Figure 15). 

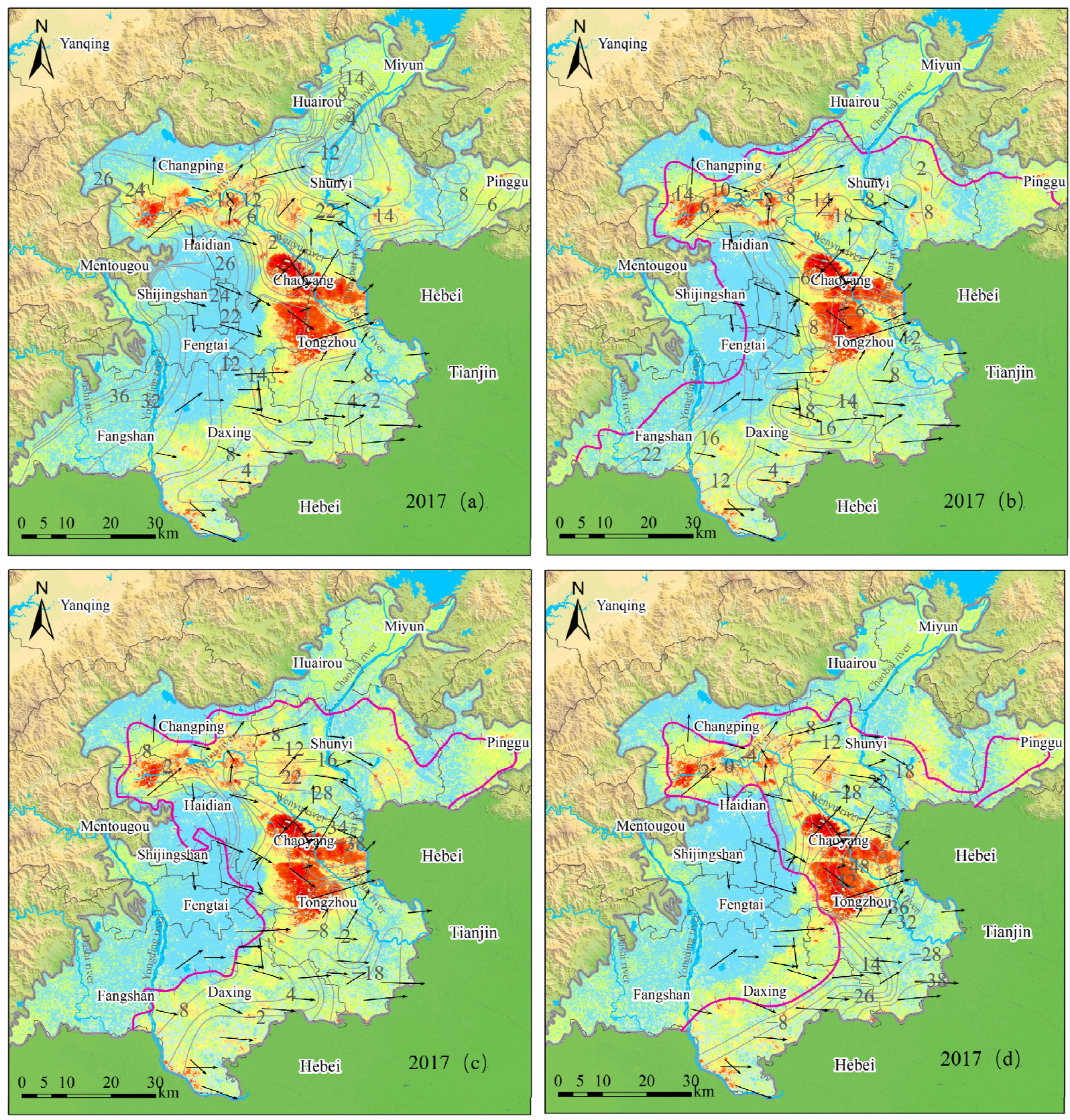

+++ Different aquifer boundary

Water table elevation of different aquifers (m)

GPS horizontal deformation $(20 \mathrm{~mm} / \mathrm{y})$

$8=-140$ deformation ( $\mathrm{mm}$ )

Figure 15. The relationship between the groundwater funnel and the 3D deformation of the land surface. (a) Unconfined aquifer. (b) First confined aquifer. (c) Second confined aquifer. (d) Third confined aquifer.

It can be seen in Figure 15a,b that in part of Haidian, Changping, and Shunyi in the northern plain, the horizontal deformation velocity of GPS points was $8.9 \sim 21.2 \mathrm{~mm} / \mathrm{y}$, and the direction of movement generally pointed to the center of land subsidence or groundwater funnel. It can be seen in Figure 15c, d that in Chaoyang and Tongzhou, where land subsidence developed severely, the distribution of land subsidence was more consistent with the second confined aquifer and (top and bottom buried depth of 100 180 $\mathrm{m}$ ) and the third confined aquifer (top and bottom buried depth of 180 300 m); the horizontal movement velocity obtained by GPS points were $8.5 \sim 24.5 \mathrm{~mm} / \mathrm{y}$; the direction of movement generally pointed to the center of the land subsidence and the funnel of the groundwater, 
and the horizontal movement velocity gradually increased from the center of the funnel or the center of the groundwater to the outside. The main reason is that the edge of the groundwater funnel was the critical zone of stratum deformation, and there was a tensile strain zone in the direction pointing to the center of the groundwater funnel $[31,33,34]$. At the same time, in the western urban area located in the land subsidence funnel of Chaoyang and Tongzhou, Fengtai, and Daxing, the horizontal movement direction obtained by GPS points demonstrated the trend of moving from areas with higher groundwater levels to areas with lower groundwater level. In addition, there is also a situation in Figure 15 where the horizontal movement direction of some GPS points was inconsistent with the law mentioned above. The main reasons are as follows: Firstly, the surface deformation was caused by multiple wells pumping water at the same time, and small groundwater funnels may exist outside the groundwater funnel area in Figure 15. Secondly, the material composition of the aquifer was characteristic of heterogeneity and anisotropy, which resulted in uneven distribution of the material composition of the aquifer. Therefore, it can be further proved that the extraction of groundwater is also the main cause of the horizontal deformation of the Beijing Plain.

\section{Conclusions}

By combining InSAR and GPS technology, this study has obtained time-series information of the 3D surface deformation in the Beijing Plain, analyzing its spatial distribution characteristics and evolution laws. On this basis, the observation data of tectonic structure, groundwater flow field, and groundwater level have been couple analyzed with the monitoring results of the 3D deformation. Meanwhile, the relationship between different influencing factors with the 3D deformation of the surface has been analyzed as well. The results of this study can be used to provide an important data basis and reference for further research on the causal mechanism of the 3D deformation and the construction of the water-soil 3D model in the Beijing Plain. The main conclusions are as follows:

(1) Under the additional stress of the Quaternary system caused by pumping, the surface of the Beijing Plain shows significant 3D deformation characteristics. The deformation is mainly vertical, supplemented by horizontal. (2) From 2013 to 2018, the land subsidence was mainly concentrated in the eastern, northern, and southern regions of the Beijing Plain. There were multiple subsidence centers, and the land subsidence generally presented a decreasing trend. Chaoyang and parts of Tongzhou, which are situated in the east of the Beijing Plain, are residential areas severely affected by land subsidence. The subsided rate exceeded $100 \mathrm{~mm} / \mathrm{y}$ for many years. The maximum settlement rate was $143.20 \mathrm{~mm} / \mathrm{y}$, the maximum accumulated settlement was $816.77 \mathrm{~mm}$, and the uneven settlement was obvious.

(2) Under the ITRF2005 reference frame, the horizontal direction of all GPS points in the plain are basically the same, with the movement mainly in the SE direction and with the dominant movement direction NE112.5 $\sim$ NE113.8 ${ }^{\circ}$. The movement speed in the E direction is $27.12 \sim 36.19 \mathrm{~mm} / \mathrm{y}$ and the average value $30.78 \mathrm{~mm} / \mathrm{y}$; the movement speed in the $\mathrm{N}$ direction is $-10.90 \sim-19.73 \mathrm{~mm} / \mathrm{y}$, and the average value $-13.57 \mathrm{~mm} / \mathrm{y}$. Under the Eurasian reference frame, the horizontal movement rate of GPS points significantly decreases, with the inconsistency changes between the points obvious. The movement rate and direction of each point are not characteristic of overall trend activity. In particular, the areas with severe land subsidence at the junction of several major active faults are often the areas with high horizontal movement rates of GPS points.

(3) The distribution and the boundary of the 3D surface deformation in the Beijing Plain are obviously controlled by the basement structure. The land subsidence area is divided by several active faults, part of which coincides with the Quaternary depression at the junction of the active faults. In areas where active faults pass through, the land subsidence profile shows an obvious turn or abrupt change. The uneven land subsidence on both sides of the faults is very obvious. Similarly, the regional basement structure controls the distribution of horizontal deformation in the E-W direction and S-N direction 
of the plain. Several major faults become the boundary of horizontal deformation. There is an obvious difference in the direction of horizontal deformation on both sides of the faults.

(4) Groundwater exploitation is the main cause of the 3D surface deformation in the Beijing Plain. With the decline or rise of the groundwater level, the soil layer shows the characteristics of compression-rebound or slowing down of compression. The groundwater funnels of the second and third confined aquifer are in suitable agreement with the land subsidence, mainly contributing to it. The horizontal movement direction of GPS points generally moves toward the center of land subsidence or groundwater funnel or moves from areas with higher groundwater levels to areas with lower groundwater levels. This is mainly caused by the horizontal deformation component of the Quaternary aquifer system due to the extraction of groundwater.

Author Contributions: Conceptualization, K.L. and F.M.; methodology, K.L.; software, K.L., H.L. and T.S.; validation, K.L., B.C. and Y.L.; formal analysis, K.L. and F.M.; investigation, K.L.; resources, K.L. and F.M.; data curation, K.L.; writing—original draft preparation, K.L.; writing-review and editing, K.L., F.M., B.C. and Y.L.; visualization, K.L.; supervision, F.M.; project administration, W.C. and Y.Z.; funding acquisition, K.L., F.M., and B.C. All authors have read and agreed to the published version of the manuscript.

Funding: This research is supported by the Beijing Natural Science Foundation (Grant No. 8212042), National Natural Science Foundation of China (Grant No. 41831293, 41771455), the Beijing Outstanding Young Scientist Program (Grant No. BJJWZYJH01201910028032), and the Beijing Youth Top Talent Project.

Data Availability Statement: Not applicable.

Conflicts of Interest: The authors declare no conflict of interest.

\section{References}

1. Hu, R.; Yue, Z.; Wang, L.; Wang, S. Review on current status and challenging issues of land subsidence in China. Eng. Geol. 2004, 76, 65-77. [CrossRef]

2. Pritchard, M.E.; Simons, M. A satellite geodetic survey of large-scale deformation of volcanic centres in the central Andes. Nature 2002, 418, 167-171. [CrossRef]

3. Jo, M.J.; Jung, H.S.; Won, J.S.; Lundgren, P. Measurement of three-dimensional surface deformation by Cosmo-SkyMed X-band radar interferometry: Application to the March 2011 Kamoamoa fissure eruption, Kīlauea Volcano, Hawai'i. Remote Sens. Environ. 2015, 169, 176-191. [CrossRef]

4. Hu, J.; Chu, H.; Hou, C.; Lai, T.; Chen, R.; Nien, P. The contribution to tectonic subsidence by groundwater abstraction in the Pingtung area, southwestern Taiwan as determined by GPS measurements. Quat. Int. 2006, 147, 62-69. [CrossRef]

5. Samsonov, S.V.; Tiampo, K.F.; Rundle, J.B. Application of DInSAR-GPS optimization for derivation of three-dimensional surface motion of the southern California region along the San Andreas fault. Comput. Geosci. 2008, 34, 503-514. [CrossRef]

6. Chen, Q.; Liu, G.; Hu, Z.; Ding, X.; Yang, Y. Mapping ground 3-D displacement with GPS and PS-InSAR networking in the Pingtung area, southwestern Taiwan. Chin. J. Geophys. 2012, 55, 3248-3258. [CrossRef]

7. Zhang, Y.; Gong, H.; Gu, Z.; Wang, R.; Li, X.; Zhao, W. Characterization of land subsidence induced by groundwater withdrawals in the plain of Beijing city. Hydrogeol. J. 2014, 22, 397-409. [CrossRef]

8. Lei, K.; Luo, Y.; Liu, H. Land Subsidence Monitoring Report of Beijing in 2019; Beijing institute of Hydrogeology and Engineering Geology: Beijing, China, 2019.

9. Zhu, L.; Gong, H.; Chen, Y.; Wang, S.; Ke, Y.; Guo, G.; Li, X.; Chen, B.; Wang, H.; Teatini, P. Effects of Water Diversion Project on groundwater system and land subsidence in Beijing. Eng. Geol. 2020, 276, 105763. [CrossRef]

10. Ferretti, A.; Prati, C. Nonlinear subsidence rate estimation using permanent scatterers in differential SAR interferometry. IEEE Trans. Geosci. Remote Sens. 2000, 38, 2202-2212. [CrossRef]

11. Hooper, A.; Zebker, H.; Segall, P.; Kampes, B. A new method for measuring deformation on volcanoes and other natural terrains using InSAR persistent scatterers. Geophys. Res. Lett. 2004, 31, 1-5. [CrossRef]

12. Ge, L.; Ng, H.; Li, X.; Abidin, H.Z.; Gumilar, I. Land subsidence characteristics of Bandung Basinas revealed by ENVISAT ASAR and ALOS PALSAR interferometry. Remote Sens. Environ. 2014, 154, 46-60. [CrossRef]

13. Qu, F.; Zhang, Q.; Lu, Z.; Zhao, C.; Yang, C.; Zhang, J. Land subsidence and ground fissures in Xi'an, China 2005-2012 revealed by multi-band InSAR time-series analysis. Remote Sens. Environ. 2014, 155, 366-376. [CrossRef]

14. Bonì, R.; Herrera, G.; Meisina, C. Twenty-year advanced dinsar analysis of severe land subsidence: The alto guadalentín basin (spain) case study. Eng. Geol. 2015, 198, 40-52. [CrossRef] 
15. Castellazzi, P.; Arroyo, N.; Martel, R.; Calderhead, A.I.; Normand, J.C.; Gárfias, J.; Rivera, A. Land subsidence in major cities of central Mexico: Interpreting InSAR-derived land subsidence mapping with hydrogeological data. Int. J. Appl. Earth Obs. Geoinf. 2016, 47, 102-111. [CrossRef]

16. Galloway, D.L.; Burbey, T.J. Review: Regional land subsidence accompanying groundwater extraction. Hydrogeology 2011, 19, 1459-1486. [CrossRef]

17. Ma, F.; Wei, A.; Han, Z.; Zhao, H.; Guo, J. The Characteristics and Causes of Land Subsidence in Tanggu Based on the GPS Survey System and Numerical Simulation. Acta Geol. Sin. 2011, 85, 1495-1507. [CrossRef]

18. Hu, B.; Wang, H.; Sun, Y.; Hou, J.; Liang, J. Long-term land subsidence monitoring of Beijing (China) using the small baseline subset (SBAS) technique. Remote Sens. 2014, 6, 3648-3661. [CrossRef]

19. Zhang, Y.; Wu, H.; Kang, Y.; Zhu, C. Ground subsidence in the Beijing-Tianjin-Hebei region from 1992 to 2014 revealed by multiple SAR stacks. Remote Sens. 2016, 8, 675. [CrossRef]

20. Chen, B.; Gong, H.; Li, X.; Lei, K.; Zhu, L.; Gao, M.; Zhou, C. Characterization and causes of land subsidence in Beijing. Int. J. Remote Sens. 2017, 38, 808-826. [CrossRef]

21. Corbau, C.; Simeoni, U.; Zoccarato, C.; Mantovani, G.; Teatini, P. Coupling land use evolution and subsidence in the Po Delta, Italy: Revising the past occurrence and prospecting the future management challenges. Sci. Total Environ. 2019, 654, 1196-1208. [CrossRef] [PubMed]

22. Gambolati, G.; Teatini, P. Geomechanics of subsurface water withdrawal and injection. Water Resour. 2015, 51, 3922-3955. [CrossRef]

23. Zhu, L.; Gong, H.; Li, X.; Wang, R.; Chen, B.; Dai, Z.; Teatini, P. Land subsidence due to groundwater withdrawal in the northern Beijing plain, China. Eng. Geol. 2015, 193, 243-255. [CrossRef]

24. Lei, K.; Luo, Y.; Chen, B.; Guo, G.; Zhou, Y. Distribution characteristics and influence factors of land subsidence in Beijing area Geol. China 2016, 43, 2216-2225. [CrossRef]

25. Gong, H.; Pan, Y.; Zheng, L.; Li, X.; Zhu, L.; Zhang, C.; Huang, Z.; Li, Z.; Wang, H.; Zhou, C. Long-term groundwater storage changes and land subsidence development in the North China Plain (1971-2015). Hydrogeology 2018, 26, 1417-1427. [CrossRef]

26. Du, Z.; Ge, L.; Ng, H.; Zhu, Q.; Yang, X.; Li, L. Correlating the subsidence pattern and land use in Bandung, Indonesia with both Sentinel-1/2 and ALOS-2 satellite images. Int. J. Appl. Earth Obs. Geoinf. 2018, 67, 54-68. [CrossRef]

27. Jiang, L.; Bai, L.; Zhao, Y.; Cao, G.; Wang, H.; Sun, Q. Combining InSAR and hydraulic head measurements to estimate aquifer parameters and storage variations of confined aquifer-system in Cangzhou, North China Plain. Water Resour. 2018, 54, 8234-8252. [CrossRef]

28. Chen, B.; Gong, H.; Lei, K.; Li, X.; Zhou, C.; Gao, M.; Guan, H.; Lv, W. Land subsidence lagging quantification in the main exploration aquifer layers in Beijing plain. Int. J. Appl. Earth Obs. Geoinf. 2019, 75, 54-67. [CrossRef]

29. Hu, L.; Dai, K.; Xing, C.; Li, Z.; Tomás, R.; Clark, B.; Shi, X.; Chen, M.; Zhang, R.; Qiu, Q.; et al. Land subsidence in Beijing and its relationship with geological faults revealed by Sentinel-1 InSAR observations. Int J. Appl. Earth Obs. Geoinf. 2019, 82, 101886. [CrossRef]

30. Burbey, T.J. Effects of horizontal strain in estimating specific storage and compaction in confined and leaky aquifer systems. Hydrogeol. J. 1999, 7, 521-532. [CrossRef]

31. Wang, Q.; Liu, Y.; Chen, Z.; Wang, W. Horizontal strain of aquifer induced by groundwater pumping-A new mechanism for ground fissure movement. J. Eng. Geol. 2002, 10, 46-50. [CrossRef]

32. Helm, D.C. Three-dimensional consolidation theory in terms of the velocity of solids. Geotechnique 1987, 37, 369-392. [CrossRef]

33. Helm, D.C. Horizontal aquifer movement in a Theis-Thiem confined system. Water Resour. Res. 1994, 30, 953-964. [CrossRef]

34. Wang, Q.; Wang, W.; Liang, W.; Liu, L. Horizontal aquifer movement induced by groundwater pumping and its applications to the analysis of some geological disasters. Acta Seismol. Sin. 1997, 10, 535-543. [CrossRef]

35. Burbey, T.J.; Warner, S.M.; Blewitt, G.; Bell, J.W.; Hill, E. Three-dimensional deformation and strain induced by municipal pumping, part 1: Analysis of field data. J. Hydrol. 2006, 330, 422-434. [CrossRef]

36. Galloway, D.L.; Hudnut, K.W.; Ingebritsen, S.; Phillips, S.P.; Peltzer, G.; Rogez, F.; Rosen, P.A. Detection of aquifer system compaction and land subsidence using interferometric synthetic aperture radar, Antelope Valley, Mojave Desert, California. Water Resour. Res. 1998, 34, 2573-2585. [CrossRef]

37. Ferretti, A.; Prati, C.; Rocca, F. Permanent scatterers in SAR interferometry. IEEE Trans. Geosci. Remote Sens. 2001, 39, 8-20. [CrossRef]

38. Hoffmann, J.; Zebker, H.A.; Galloway, D.L.; Amelung, F. Seasonal subsidence and rebound in Las Vegas Valley, Nevada, observed by synthetic aperture radar interferometry. Water Resour. 2001, 37, 1551-1566. [CrossRef]

39. Hoffmann, J.; Galloway, D.L.; Zebker, H.A. Inverse modeling of interbed storage parameters using land subsidence observations, Antelope Valley, California. Water Resour. 2003. [CrossRef]

40. Hooper, A. A multi-temporal InSAR method incorporating both persistent scatterer and small baseline approaches. Geophys. Res. Lett. 2008, 35, 96-106. [CrossRef]

41. Tomas, R.; Herrera, G.; Lopez-Sanchez, J.M.; Vicente, F.; Cuenca, A.; Mallorqui, J.J. Study of the land subsidence in Orihuela City (SE Spain) using PSI data: Distribution, evolution and correlation with conditioning and triggering factors. Eng. Geol. 2010, 115, 105-121. [CrossRef] 
42. Zhou, C.; Gong, H.; Chen, B.; Li, J.; Gao, M.; Zhu, F.; Chen, W.; Liang, Y. InSAR time-series analysis of land subsidence under different land use types in the Eastern Beijing Plain, China. Remote Sens. 2017, 9, 380. [CrossRef]

43. Chen, B.; Gong, H.; Chen, Y.; Li, X.; Zhou, C.; Lei, K.; Zhu, L.; Duan, L.; Zhao, X. Land subsidence and its relation with groundwater aquifers in Beijing Plain of China. Sci. Total Environ. 2020, 735, 139111. [CrossRef] [PubMed]

44. Dong, D.; Fang, P.; Bock, Y.; Cheng, M.; Miyazaki, S. Anatomy of apparent seasonal variations from GPS derived site position time series. J. Geophys. 2002, 107, 2075. [CrossRef]

45. Yao, Y.B. Analysis of crustal movement characteristics in the China mainland by high precision repeated measurements of GPS network. Prog. Geophys. 2008, 23, 1030-1037.

46. Feng, G.C.; Li, Z.W.; Shan, X.J.; Xu, B.; Du, Y. Source parameters of the $2014 \mathrm{Mw} 6.1$ South Napa earthquake estimated from the Sentinel 1A, COSMO-SkyMed and GPS data. Tectonophysics 2015, 655, 139-146. [CrossRef]

47. Li, Z.; Zhang, P.; Ding, K.; Jiang, Z.; Chen, X. Inversion of tectonic strain field in China continent using integrated data of GPS velocity field and seismic moment tensor. Sci. Surv. Mapp. 2016, 41, 60-64. [CrossRef]

48. Zheng, G. The use of long-term GPS observation to analyze present-day slip rate and crustal activity characteristic of the Kunlun fault. J. Geod. Geodyn. 2019, 39, 557-561.

49. Wei, W.S.; Lv, X.J.; Cai, X.M. Beijing Urban Geology; China Land Press: Beijing, China, 2008.

50. Cai, X.; Luan, Y.; Guo, G.; Liang, Y. 3D Quaternary geological structure of Beijing plain. Geol. China 2009, 36, 1021-1029. [CrossRef]

51. Jia, S.; Wang, H.; Zhao, S.; Luo, Y. A tentative study of the mechanism of land subsidence in Beijing. City Geol. 2007, 2, 20-26. [CrossRef]

52. Malinowska, A.A.; Witkowski, W.T.; Hejmanowski, R.; Chang, L.; van Leijen, F.J.; Hanssen, R.F. Sinkhole occurrence monitoring over shallow abandoned coal mines with satellite-based persistent scatterer interferometry. Eng. Geol. 2019, 262, 105336. [CrossRef]

53. Strozzi, T.; Carreon-Freyre, D.; Wegmüller, U. Land subsidence and associated ground fracturing: Study cases in central Mexico with ALOS-2 PALSAR-2 ScanSAR Interferometry. Proc. IAHS 2020, 382, 179-182. [CrossRef]

54. Teatini, P.; Strozzi, T.; Tosi, L.; Wegmüller, U.; Werner, C.; Carbognin, L. Assessing short- and long-time displacements in the Venice coastland by synthetic aperture radar interferometric point target analysis. J. Geophys. Res. Earth Surf. 2007, 112, F01012. [CrossRef] 